\title{
The Power of the States to Tax Intangibles or Their Transfer
}

PerHaps no case in recent years has caused as much comment and
speculation as to what the law in the future will be as that of Farm-
ers Loan and Trust Company v. Minnesota, ${ }^{1}$ decided last January by
the United States Supreme Court, and discussed at considerable length
in the May issue of the California Law Reviewe. ${ }^{2}$ The case held that the
State of Minnesota had no power, because of the Fourteenth Amend-
ment, to levy an inheritance tax on the transfer of registered bonds of
the cities of Minneapolis and St. Paul, owned by a non-resident dece-
dent, and kept in New York. ${ }^{3}$ The holding was neither startling nor

1 (January 6, 1930) 280 U. S. 204, 50 Sup. Ct. 98, 65 A. L. R. 1000, reversing Estate of Taylor (1928) 175 Minn. 314, 221 N. W. 64. See Note (1929) 27 MIch. L. REv. 447; (1929) 13 MINN. L. REv. 273, and Nossaman, The Fourteenth Amendment in its Relation to State Taxation of Intangibles (1930) 18 CArIF. L. REv. 345, 346, note 3 .

2 Nossaman, The Fourteenth Amendment in its Relation to State Taxation of Intangibles (1930) 18 CAIIF. L. REv. 345. For excellent discussion of case, see Note (1930) 43 HaRv. L. Rev. 792. See also Ohlander, Double Taxation and State Inheritance Taxes (1930) 8 NaT. INc. TAX MAG. 253; Brady, Death Taxes (1930) 16 Arr. Bar Assn. J. 532; Note (1930) 10 B. U. L. REv. 423; Note (1930) 4 CnNN. L. REv. 398 (discussing effect on Ohio statutes); (1930) 30 CoL. L. Rev. 404; Note (1930) 15 CoRN. L. Q. 457; Note (1930) 18 GEO. L. J. 364; Note (1930) 28 Mich. L. Rev. 916; Note (1930) 14 MrnN. L. Rev. 799; Note (1930) 8 N. CaR.. L. Rev. 318; Note (1930) 7 N. Y. U. L. Q. REv. 728; (1930) Sr. JoHr's L. REv. 322 ; Note (1930) 3 So. CaI. L. Rev. 428; Note (1930) 64 U. S. L. Rev. 158; Note (1930) 16 VA. L. REv. 470; (1930) 5 WASH. L. REv. 132; Note (1930) 5 WIs. L. REv. 441. For more conservative viewpoints, see Nossman, supra, and Harper, Jurisdiction of the States to Tax (1930) 5 IND. L. J. 507; (1930) 9 ORE. L. REv. 370.

3 As has been pointed out, the facts presented an unusually strong case for the domicile of the debtor, since (1) the debtors were mumcipalities of Minnesota, and therefore could not be sued outside the state, and (2) the bonds were registered. See Note (1930) 43 HaRv. L. REv. 792, 794, note 16. A discussion of these circumstances follows:

(1) Absolute necessity of suing in the state where debtor is domiciled if suit is brought at all. This circumstance is given controlling importance in some jurisdictions. Thus it is held that in order to predicate jurisdiction to tax on the domicile of the debtor, the things mortgaged as security for the debt must be situated entirely in the state of the debtor's domicile; that when the debt is secured in part by land in the debtor's state and in part by land in other states, the debtor's domicile has no jurisdiction to tax, although it would have such jurisdiction in the former case. Where the debt may by any possibility be collected without resort to the courts of the debtor's state, the latter has no jurisdiction. Bliss v. Bliss (1915) 221 Mass. 201, 109 N. E. 148, L. R. A. 1916A 889; State v. Chadwick (1916) 133 Minn. 117, 157 N. W. 1076, 158 N. W. 637, L. R. A. 1916E 1288; State ex rel. Walker v. Jones (1927) 80 Mont. 574, 261 Pac. 356, 60 A. L. R. 551. 
unusual in itself, inasmuch as many of the state courts had practically held to the same effect. ${ }^{4}$ The unusual feature of the case was the sweep-

(2) Registration. The fact that the bonds were registered was regarded as an immaterial circumstance by the Court in the Farmers' Loan case. 280 U. S. at 208, 50 Sup. Ct. at 99, 65 A. L. R. at 1002. As pointed out by Nossaman, supra note 1 , at 349 , there is a substantial difference of opinion as to the immateriality of this circumstance. The following cases hold registration to be an immaterial circumstance: Estate of Taylor (1928) 175 Minn. 310, 219 N. W. 153 ; Tax Commission of Ohio v. Farmers' Loan and Trust Company (1928) 119 Ohio St. 410, 164 N. E. 423,60 A. L. R. 546 (also part of the litigation involving the Taylor estate); Royal Trust Company v. Attorney General for Alberta [1930] A. C. 144. It is held to the contrary in Massachusetts. Bliss v. Bliss, supra. In the latter case, the court said: "Since the tax is upon succession to property, it may be levied by the State where the succession of necessity inust take place; or in other words, where alone the effectual transfer of the legal title, as manifested by the essential factor of change of registration, can be consunnmated. . . . Complete indicia of legal title does not pass to the purchaser of such a bond except by transfer by registration." 221 Mass. at 207, 109 N. E. at 150.

It would seem that the provision for registration of the bonds is as much a hasis for a tax on the bonds by the state of registration as is the provision for transfer of shares of stock on the books of the corporation does for a tax by the state where those hooks are situated. Both provisions are designed to carry out the same general purpose i.e. to protect the corporation or obligor in the payment of dividends on the one hand, and interest on the other, and also to serve a purpose similar to the recording acts in the case of real property - protection of bona fide purchasers from the registered owner. Both shares of stock and bonds are a product of an originating instrument, articles of incorporation on the one hand, and a trust indenture on the other, whereby the aliquot shares of many in a given enterprise are determined. Since it has heen held that shares of stock may be taxed at the place where the transfer books are kept, (Erie Beach Company v. Attorney General for Ontario [1930] A. C. 161) so should registered bonds be taxable at the place of registration, by any jurisdiction accepting the Erie case. Jurisdictions accepting that case most likely will not be found in this country in the future, in view of Baldwin v. Missouri (1930) 281 U. S. 586, 50 Sup. Ct. 436, later to be discussed. However, it should be noted that the above argument as to registered bonds was rejected by the Privy Council in Royal Trust Company v. Attorney General for Alberta, supra at 151, where Lord Merrivale said, "The conditions of the bonds as to registration are in no way analogous to the provisions in articles of association for the incorporation of shareholders in a joint stock company" ... so as to apply the primciple affirmed in Brassard v. Smith [1925] A. C. 371, 373, 376. Why such conditions are "in no way analogous," Lord Merrivale does not, and it is submitted, could not, point out. See also Note (1930) 43 HaRv. L. REv. 792, 794, note 16.

4 Chambers v. Mumford (1921) 187 Cal. 228, 201 Pac. 588, 42 A. L. R. 342 ; Walker v. People (1918) 64 Colo. 143, 171 Pac. 747, 8 A. L. R. 855; People v. Blair (1917) 276 ㄱll. 623, 115 N. E. 218; Dodge County v. Burns (1911) 89 Neb. 534,131 N. W. 922,35 L. R.A. (N.s.) $877 ; \operatorname{Re}$ Bronson (1896) 150 N. Y. 1, 44 N. E. 707; Re Fearing (1911) 200 N. Y. 340, 93 N. E. 956; Tax Cominission of Ohio v. Farmers' Loan and Trust Company (1928) 119 Ohio St. 410, 164 N. E. 423, 60 A. L. R. 546; Fuller v. South Carolina Tax Commission (1924) 128 S. C. 14, 121 S. E. 478; McLaughlin v. Cluff (1925) 66 Utah 245, 240 Pac. 161, 42 A. L. R. 347; Commonwealth v. Huntington (1927) 148 Va. 97, 138 S. E. 650. See also Note (1921) 10 CAIIF. L. REv. 151; Note (1925) 24 MicE. L. REv. 595; Note (1928) 6 N. CAR. L. REv. 66; Nossaman, supra note 2, at 348. It is of course true that most of these cases were construing statutes to the effect that all prop- 
ing language used by the Court, speaking through Mr. Justice McReynolds, indicating that it was prepared to turn a complete about-face from its previous attitude toward the taxation of intangibles, and that the doctrine of stare decisis was not to be considered a serious obstacle to the carrying into effect of this new policy. 5 The Court practically

erty "within the state," or "within the jurisdiction" shall be subject to taxation, and many expressly disclaimed any intention to hold that the state had no constitutional power to levy such a tax. But it is dificult to see how a legislature can more unmistakably evince a purpose to tax all the property it is constitutionally able to tax than by using such terms as these. Consequently, these decisions really stand for the proposition that the state where the obligor is domiciled may not tax bonds held by a non-resident, because such property is not within its jurisdiction. When a tax of this type is held to deny due process, it is usually on the ground that the property sought to be taxed is not "within the jurisdiction" of the taxing state, or is not "within the state." Frick v. Pennsylvania (1925) 268 U. S. 473, 45 Sup. Ct. 603, 42 A. L. R. 316; Farmers' Loan and Trust Coinpany v. Minnesota (1930) 280 U. S. 204, 50 Sup. Ct. 98, 65 A. L. R. 1000. Therefore the questions are suhstantially the same whether a constitutional "due process" clause is involved, or a statute purporting to tax all property "within the state" or "within the jurisdiction," unless a strict construction of taxing statutes against the government or a construction against double taxation is invoked. See Kroeger, Constitutional Limitations of Stale Jurisdiction over Property for Succession Tax Purposes (1929) 14 Sr. LouIs L. Rev. 99, 115. It has been said: "Is there such a difference between the statutory connotation of property 'within the state' and the constitutional connotation of that term, which ought to lead to a different result when applied to property in the same situation so far as the state jurisdiction is concerned? Such difference, if it exists, inust be postulated on the doctrime that taxing statutes must be strictly construed against the sovereign. But ought not an equally strict construction of what constitutes property 'within the state' be employed when constitutional lunitations are concemed? While the mcidence of double or triple taxation by various states of a succession may be without constitutional objection, it furnishes substantial reason why the highest court of the land should equally strictly construe the doctrine of jurisdiction over property, when a state attempts to impose a tax on the basis of so tenuous a ground of jurisdiction over a debt as jurisdiction over the debtor?" Kroeger, Constitutional Limitations of State Jurisdictions over Property for Succession Tax Purposes (1929) 14 Sr. Lours L. Rev. 99, 116.

5 The attitude of the Court as to double taxation was foreshadowed by the language im Safe Deposit and Trust Company v. Virginia (1929) 280 U. S. 83, 50 Sup. Ct. 59. The Court said: "The reasons which led this court in Union Refrig. Transit Co. v. Kentucky, 199 U. S. 194, and Frick v. Pennsylvania, 268 U. S. 473, to deny the application of the maxim mobilia sequuntur personam to tangibles apply to the imtangibles in appellant's possession. They have acquired a situs separate from that of the beneficial owners. The adoption of a contrary rule would 'involve possibilities of an extremely serious character' by permitting double taxation, both unjust and oppressive." $280 \mathrm{U}$. S. at 93, 50 Sup. Ct. at 61 . The case involved an attempt by Virginia to levy a property tax measured by the whole corpus of a trust fund consisting of intangibles and kept at the residence cf the trustee in Maryland. The beneficiaries were minors, domiciled in Virginia, and the corpus was to be distributed to them on attaining twenty-five years of age. The Court held the tax invalid as attempting to reach property beyond the jurisdiction, inasinuch as the cestuis had no present right of enjoyment. Although it has been supposed that the case holds that the state of the cestui's domicile may 
admitted that it was wrong in nearly a score of earlier cases, ${ }^{6}$ but declared in effect that it was ready to make amends for its past mistakes.

The main points in the opinion of Mr. Justice McReynolds were as follows:

(1) Multi-state taxation of intangibles is an evil, which will not be tolerated by the Court in the future. ${ }^{7}$

not tax his interest in intangibles, (see Note (1930) 30 Coc. L. Rev. 539, at 543) the Court expressly disclaims any intention to so hold: "The power of Virginia to lay a tax upon the fair value of any interest in the securities actually owned by one of her resident citizens is not now presented for consideration." $280 \mathrm{U}$. S. at 92,50 Sup. Ct. at 60 . See also concurring opinion of Mr. Justice Stone 280 U. S. at 95, 50 Sup. Ct. at 61 . The case was therefore controlled by Brooke v. Norfolk (1928) 277 U. S. 27, 48 Sup. Ct. 422; and Maguire v. Trefry (1920) 253 U. S. 12, 40 Sup. Ct. 417. See Note (1930) 78 U. of PA. L. Rev. 532, at 534. Cf. however, an attempt to distinguish Brooke v. Norfolk (1929) 42 HaRv. L. REv. 712. The problem of multi-state taxation arising from the creation of trusts is treated in Note (1930) 30 Cos. L. REv. 539, and will not be further considered here. See also Nossaman, supra note 2 , at 361,367 ; (1930) 43 Harv. L. REv. 668; Note (1930) 78 U. of PA. L. REv. 532; (1930) 39 YALE L. J. 589. In general see Beale, Jurisdiction to Tax (1919) 32 HARv. L. REv. 587, 619; Maxey, Situs of Personal Property for Purposes of Taxation (1919) 3 MINN. L. REv. 217, 239; Goodrich, Conflict of Laws (1927) §54; Note (1925) 14 CaIIT. L. Rev. 225; Note (1929) 15 VA. L. REv. 696.

6 The repudiation of multi-state taxation of imtangibles runs afoul a basic assumption, if not the actual holding, in the following cases: New Orleans v. Stempel (1899) 175 U. S. 309, 20 Sup. Ct. 110; Bristol v. Washington County (1900) 177 U. S. 133, 20 Sup. Ct. 585; Blackstone v. Miller (1903) 188 U. S. 189, 23 Sup. Ct. 277; Kidd v. Alabama (1903) 188 U. S. 730, 23 Sup. Ct. 401; Board of Assessors v. Comptoir National d'Escompte (1903) 191 U. S. 388, 24 Sup. Ct. 109; Scottish Union and National Ins. Co. v. Bowland (1905) 196 U. S. 611, 25 Sup. Ct. 345; Umion Refrigerator Transit Coinpany v. Kentucky (1905) 199 U. S. 194, 26 Sup. Ct. 36; Metropolitan Life Ins. Co. v. New Orleans (1907) 205 U. S. 395, 27 Sup. Ct. 499; Liverpool \& London \& Globe Ins. Co. v. Board of Assessors (1911) 221 U. S. 346, 31 Sup. Ct. 550, L. R. A. 1915C 903; Orient Ins. Co. v. Board of Assessors (1911) 221 U. S. 358, 31 Sup. Ct. 554; Hawley v. Malden (1914) 232 U. S. 1, 34 Sup. Ct. 201, Ann. Cas. 1916C 842; Wheeler v. Sohmer (1914) 233 U. S. 434, 34 Sup. Ct. 607; Rogers v. Hennepin County (1916) 240 U. S. 184, 36 Sup. Ct. 265; Bullen v. Wisconsin (1916) 240 U. S. 625, 36 Sup. Ct. 473; Fidelity \& Columbia Trust Co. v. Louisville (1917) 245 U. S. 54, 38 Sup. Ct. 40, L. R. A. 1918C 124; Cream of Wheat Co. v. Grand Forks County (1920) 253 U. S. 325, 40 Sup. Ct. 558; Citizens Nat. Bank v. Durr (1921) 257 U. S. 99, 42 Sup. Ct. 15; Frick v. Pennsylvania (1925) 268 U. S. 473, 45 Sup. Ct. 603, 42 A. L. R. 316; Blodgett v. Silberman (1928) 277 U. S. 1, 48 Sup. Ct. 410.

7 Mr. Justice McReynolds said: "Four different views concerning the situs for taxation of negotiable public obligations have been advanced. One fixes this at the domicile of the owner; another at the debtor's domicile; a third at the place where the instruments are found - physically present; and the fourth within the jurisdiction where the owner has caused them to become integral parts of a localized business. If each State can adopt any one of these and tax accordingly, obviously, the same bonds may be declared present for taxation in two, or three, or four places at the same moment. Such a startling possibility suggests a wrong premise." 280 U. S. at 209, 50 Sup. Ct. at 99, 65 A. L. R. at 1003. Although Mr. Justice McReynolds here paints a rather gloomy picture for bondholders, the . 
(2) Consequently, Blackstone v. Miller ${ }^{8}$ is overruled, as a first step in the process of eliminating this evil. ${ }^{\circ}$

picture is made somewhat brighter by the consideration that since 1924 at least over a half of the states had enacted reciprocal tax statutes of various sorts, exempting from taxation intangibles of residents of any state which accorded a like exemption to its own residents. See Legislation (1930) 43 HARv. L. Rzv. 641. Consequently less than half of the states were attempting in 1930 to exact the levies condemned in the Farmers' Loan case and in Baldwin v. Missouri (1930) 281 U. S. 586, 50 Sup. Ct. 436. Only Arizona, Kansas, Kentucky, Minnesota, Montana, North Dakota, Oklahoma, South Dakota and Utah do not have reciprocity statutes - 9 states, according to Note (1930) 10 B. U. L. REv. 423, $42 \%$. See also Ohlander, supra note 2; City Bank Farmers' Trust Co. v. New York Cent. R. Co. (1930) 253 N. Y. 49, 170 N. E. 489, explained in (1930) 5 U. S. DAIIY 880.

8 (1903) 188 U. S. 189, 23 Sup. Ct. 277, upholding an inheritance tax levied by New York on the transfer of a bank deposit in a New York bank owned by a non-resident. Mr. Justice White dissented. The basis of the decision was the theory that jurisdiction over the debtor gives power over the debt, and therefore jurisdiction to tax. This theory was expressly rejected in the earher case of State Tax on Foreign Held Bonds (1872) 82 U. S. (15 Wall.) 300, where it was held that the state of the debtor's domicile had no jurisdiction to levy a property tax on interest on bonds owned by a non-resident, and held outside the state. Mr. Justice Field, delivering the opinion of the Court, said: "But debts owing by corporations, like debts owing by individuals, are not the property of the debtors in any sense; they are obligations of the debtors, and only possess value in the hands of the creditors. With them they are property, and in their hands they may be taxed. To call debts property of the debtors is simply to misuse terms. All the property there can be in the nature of things in debts of corporations, belongs to the creditors, to whom they are payable, and follows their domicile, wherever that may be." 82 U. S. (15 Wall.) at 320 . The fundamental basis of Blackstone v. Miller is thus diametrically opposed to that of State Tax on Foreign Held Bonds, and consequently it has been thought that the former overruled the latter. Kroeger, supra note 4 at 113 ; Note (1929) 17 GEo. L. J. 150, 152; Note (1929) 15 VA. L. REv. 696, at 699. Cf. Note (1930) 5 Wis. L. REv. 441, 442. However, even though the cases are opposed to each other in principle, they were distinguishable on formerly tenable grounds: (1) Blackstone v. Miller involved an inleritance tax,

and not a property tax. The former is a tax on the transfer of property from the dead to the living, and not a tax on the property. Therefore jurisdiction to levy an inheritance tax on the transfer of property is broader than jurisdiction to tax that property directly. See Powell, Extra-territorial Inheritance Taxation (1920) 20 Cor. L. Rev. 1, 283. Since Frick v. Pennsylvania (1925) 268 U. S. 473, 45 Sup. Ct. 603,42 A. L. R. 316, it would seem that tbis ground of distinction no longer exists. (2) In State Tax on Foreign Held Bonds the evidences of indebtedness were held outside the taxing state. They being equivalent to tangible chattels, were outside the state, and could not be taxed. See Blackstone v. Miller (1903) 188 U. S. 189, 206, 23 Sup. Ct. 277, 279, per Mr. Justice Holmes. It would seem that this distinction also falls with the advent of Buck v. Beach (1907) 206 U. S. 392, 27 Sup. Ct. 712, 11 Ann. Cas. 732; Blodgett v. Silberman (1928) 277 U. S. 1, 48 Sup. Ct. 410, and Baldwin v. Missouri (1930) 281 U. S. 586, 50 Sup. Ct. 436. (3) That the Court did not mean what it said in Blackstone v. Miller; that it was entirely unnecessary to the decision to hold generally that the state of the debtor's dounicile could tax a debt, because the debt involved was a bank deposit, which is to be treated as cash, and not as a mere debt. Kroeger, supra note 4, at 115. But it is clear from the langnage of the Court that the real basis of their decision was the broad doctrine that the state of the debtor's domicile could $\operatorname{tax}$ a 
(3) That in general, intangibles may be taxed in the state of their owner's domicile, and no sufficient reason can be found for saying that they are not entitled to enjoy an immunity against taxation by more than one state, just as tangibles may be taxed by only one state. ${ }^{10}$

debt or its transfer. Mr. Justice Holmes said: "There is no doubt that courts in New York and elsewhere have been loath to recognize a distinction for taxing purposes between what commonly is called money in the bank and actual coin in the pocket. The practical similarity more or less has obhterated the legal difference. Matter of Houdayer, 150 N. Y. 37; New Orleans v. Stempel, 175 U. S. 309, 316; City National Bank v. Charles Baker Co., 180 Mass. 40, 42. In view of these cases, and the decision in the present case, which followed them, a not very successful attempt was made to show that by reason of the facts which we have mentioned, and others, the deposit here was unlike an ordinary deposit in a bank. We shall not stop to discuss this aspect of the case, because we prefer to decide it upon a broader view." 188 U. S. at 205, 23 Sup. Ct. at 278.

9 The overruling of Blackstone v. Miller was half-way predicted by one writer in an article written in. February, 1929. Kroeger, supra note 4 at 111, 113.

10280 U. S. at 212, 50 Sup. Ct. at 100, 65 A. L. R. at 1004. Although the law started out with the maxim mobilia sequnntur personam, which was applied to all personal property, including tangibles, the later cases have been a series of recessions from it as far as taxation of tangibles is concerned. In Pullman's Palace Car Company v. Pennsylvania (1891) 141 U. S. 18, 11 Sup. Ct. 876, and again in Adams Express Company v. Ohio State Auditor (1897) 165 U. S. 194, 166 U. S. ' 185, 17 Sup. Ct. 305, 604, it was held that tangible personal property could be taxed by the state in which it is actually situated, even though that state is not the domicile of the owner. The doctrine does not apply to tangibles only transiently present in the state. Hays v. Pacific Mail S. S. Co. (1854) 58 U. S. (17 How.) 595. However, it was later recognized that although property is only transiently in the state, it may acquire something like a "busmess situs" where there is at any one time a large mass of property in the state, although the units of this mass are constantly moving in and out of the state. American Refrigerator Transit Company v. Hall (1898) 174 U. S. 70, 19 Sup. Ct. 599. But see New York ex rel New York Cent. \& H. R. Co. v. Miller (1906) 202 U. S. 584, 26 Sup. Ct. 714. It was then held that tangible personal property could not be subjected to a property tax at the domicile of its owner when it is permanently located in another state. Delaware, Lackawanna and Western R. Co. v. Pennsylvania (1905) 198 U. S. 341, 25 Sup. Ct. 669 ; Union Refrigerator Transit Company v. Kentucky (1905) 199 U. S. 194, 26 Sup. Ct. 36, 4 Ann. Cas. 493. It is generally thought by most writers that the Union Transit case is the first case so holding. As has been pointed out in the able discussion of Professor Powell, the Delaware case stood for as much and more than the Union Transit case. Powell, supra note 8, at 287. It held that Pennsylvania could not measure a tax on capital stock of a domestic corporation by including in the measure the value of coal mined in Pennsylvania, but at the time of the tax located in another state. As the tax was not on the coal itself, but on the capital stock of a domestic corporation, there was room for the contention that the state was merely using the so-called "measurement" theory (See Traynor, National Bank Taxation in California (1929) 17 CalfF. L. Rev. 232 et seq.) to arrive at the taxable value of a subject within its absolute power. If notwithstanding, such a tax was invalid, then $a$ fortiori, the tax in the Union Transit case was invahd. Powell, loc. sit. supra note 8 . But see Moore, Taxation of Movables and the Fourteenth Amendment (1907) 7 CoL. L. REv. 309. See also GoOdrich, CONFLICT of Laws (1927) \$45.

The fiction mobilia sequuntur personam was retained in one important respect, however. Where, even conceding that the tangible personal property is per- 
Thus the majority of the Court indicated that they were prepared to brush aside at a single stroke old doctrines and precedents thought to be too well settled to admit of any question. The older cases and theories had been built around the principle that there is no constitutional objection to multi-state taxation of intangibles; that intangibles are widely different from tangibles, as the latter are visible, difficult

manently outside the state, indeed, even if it has never been physically within the state, if there is a probability that it has not acquired a taxable situs elsewhere, then it is permissible to tax it at the domicile of the owner. Southern Pacific Company v. Kentucky (1911) 222 U. S. 63, 32 Sup. Ct. 13. This would appear to be a qualification of the rule of the Union Refrigerator case. That case held that Kentucky could not tax tangible personal property of one of its residents because such property was permanently located outside Kentucky; that since it was so located,. Kentucky has no jurisdiction over it-in short, it lacked the pbysical power. If the basis of the decision is, as the language of the Court suggests, that Kentucky lacks the physical power, then the question whether such property has probably acquired a taxable situs elsewhere would seem to be irrelevant. It would appear that the Southern Pacific case narrows the Union Transit case by declaring the primciple of the latter applicable only where to deny its application would lead to double taxation. See Powell, supra note 8 , at 298.

The final step was taken in Frick v. Pennsylvania (1925) 268 U. S. 473, 45 Sup. Ct. 603, 42 A. L. R. 316. Prior to the Frick case it had been thought that even though the Union Transit case settled the law that a property tax at the domicile of the owner on tangibles permanently located in another state was invalid, that this decision.did not preclude a holding that it was permissible to levy a succession tax at the domicile of the decedent measured in part or in whole by tangible chattels permanently located in another state. A succession tax was said to rest upon a different basis than a property tax. The former, it was said, is not a tax on property, but on the privilege of succession. Therefore the state whose laws bring about the transfer from the dead to the living should be permitted to levy this tax, the argument ran. In the case of tangible chattels, the law of the decedent's domicile governs succession and is necessarily invoked ot effect a transfer of the property. Therefore, it was argued, it should be permissible to measure the tax by the whole amount of the property actually passing by the law of the domicile. This view was virtually approved in Maxwell v. Bugbee (1919) 250 U. S. 525, 40 Sup. Ct. 2. See Note (1920) 33 Harv. L. Rev. 582. A further argument could be urged in support of the tax. A succession tax being in the nature of a privilege or excise tax, aud not a tax on property (See Knowlton v. Moore (1900) 178 U. S. 41, 20 Sup. Ct. 747), a state could charge any price it wanted for the granting of that privilege, and therefore it could include in the ineasure of that tax property which it had no power to tax directly. The view had been repeatedly approved in cases involving the taxation of corporate franchises, at Icast to the extent of permitting a state to levy a tax on corporate franchise by including in the measure of the tax federal tax-exempt securities. Society for Savings v. Coite (1868) 73 U. S. (6 Wall.) 594; Provident Institution v. Massachusetts (1868) 73 U. S. (6 Wall.) 611; Haunilton Co. v. Massachusetts (1868) 73 U. S. (6 Wall.) 632; Home Insurance Company v. New York (1890) 134 U. S. 594, 10 Sup. Ct. 593. See Traynor, National Bank Taxation in California (1929) 17 CAIIF. L. REv. 232; Powell, Indirect Encroachment on Federal Authority by the Taxing Powers of the States (1918) 31 Harv. L. Rev. 321, 331. Cf. Macallen Company v. Massachusetts (1929) 279 U. S. 620, 49 Sup. Ct. 432, 65 A. L. R. 866, Note (1929) 43 HaRv. L. REv. 280. It lad also been approved in connection with taxation of intangibles. Thus thougl it was settled that a state 
to conceal, and a tax at their situs easy of collection, whereas the reverse is true of intangibles: they are not visible, are extremely easy to conceal, and a tax on them will be most easily collected at the domicile of their owner by virtue of the state's power over that owner; that in most cases intangibles will escape taxation altogether unless several states are given the opportunity to tax. ${ }^{11}$ Thus taxation by several states was sanctioned as a means of increasing the probability

cannot tax United States bonds (Weston v. Charleston (1829) 27 U. S. (2 Pet.) 289), yet it was held permissible to levy a succession tax on the transfer of such bonds. Plumner v. Coler (1900) 178 U. S. 115, 20 Sup. Ct. 829; although the state of the debtor's domicile could not levy a property tax on the debt, State Tax on Foreign Held Bonds (1872) 82 U. S. (15 Wall.) 300 , it was beld to have jurisdiction to levy a succession tax. Blackstone v. Miller (1903) 188 U. S. 189, 23 Sup. Ct. 277 , and although the state where negotiable notes were physically present could not levy a property tax on the debt (Buck v. Beach (1907) 206 V. S. 392, 27 Sup. Ct. 712), it could levy a succession tax. (Wheeler v. Sobmer (1914) 233 U. S. 434, 34 Sup. Ct. 607).

To summarize, then, there were in main two arguments in favor of the tax sought to be upheld in the Frick case: (1) that the law of the decedent's domicile was needed to effect the transfer; (2) that a succession tax is a privilege or excise tax and may be nieasured by elements which the state has no power to tax directly, in support of which Blackstone v. Miller, Wheeler v. Sohnier and Plummer v. Coler could be cited. The Court rejected both arguments in the Frick case and held the tax invalid. As to the first, it declared that although the law of the domicile was needed to transfer the property, this was only by virtue of comity on the part of the law of the situs of the tangibles; that the real power was in the state of the situs, and therefore it alone could transfer. (See Powell, Extra-territorial Inheritance Taxation (1920) 20 CoL. L. REv. 283, 305 for an argument to the contrary). As to the second, it declared that the mere fact that the $\operatorname{tar}$ is a succession tax does not renove the necessity that the subject the transfer of wbich is taxed he within the jurisdiction of the taxing state. $268 \mathrm{U}$. S. at $492,45 \mathrm{Sup}$. Ct. at $605,42 \mathrm{~A}$. L. R. at 322 . This assertion is tantamount to placing property and succession taxes on the same jurisdictional basis. Although the Court professed, in the Frick case, to see a distinction between tangibles and intangibles on this score, the Doughton, Farmers' Loan, and Baldwin cases make it clear'that no such distinction nuay now be made. See Rhode Island Hospital Trust Co. v. Doughton (1926) 270 U. S. 69, 80, 46 Sup. Ct. 256, 258, 43 A. L. R. 1374, 1379. The net result of the Frick, Doughton, Farmers' Loan and Baldwin cases is to place succession taxes on the same jurisdictional basis as property taxes. Thus it was said even before the Farmers' Loan and Baldwin cases: "I submit that it remains only to state definitely, that the privilege character of succession taxation has no further influence in extending the jurisdiction of the state to measure a succession tax by the value of property which it has no power to tax directly." Kroeger, supra note 4 , at 135. There is of course one important exception to this sweeping generalization. It is still permissible to levy a succession tax on the transfer of United States bonds. Plummer v. Coler (1900) 178 U. S. 115, 20 Sup. Ct. 829. Furthermore, to say that a succession tax is "on" the property transferred, and not the privilege of transfer would be to invahdate the Federal Estate Tax. Knowlton v. Moore (1900) 178 U. S. 41, 20 Sup. Ct. 747. For articles and notes discussing Frick v. Pennsylvania, see Nossaman, supra note 2 at 358 , note 52.

11 Union Refrigerator Transit Co. v. Kentucky (1905) 199 U. S. 194, 205, 26 Sup. Ct. 36, 38, 4 Ann. Cas. 493, 495; Frick v. Pennsylvania (1925) 268 U. S. $473,494,45$ Sup. Ct. 603, 606, 42 A. L. R. 316, 323. 
that intangibles would be taxed at least once. Occasional injustice was justified, it was said, as a mere unfortunate incident to the only means of carrying out the broader and more important principle that all property should contribute at least once to the expenses of government. $^{12}$

As a result of this line of argument, several theories grew up as to the situs of intangibles for taxation purposes. It was permissible for any one or all of the following states to tax: (1) the state where the creditor or owner of the intangible was domiciled; ${ }^{13}$ (2) the state where the debtor or obligor was domiciled; ${ }^{14}$ (3) the state where the evidences of indebtedness were physically present; ${ }^{15}$ (4) the state where the intangibles had acquired a business situs. ${ }^{10}$ All of these

12 Maxey, Situs of Personal Property for Purposes of Twaxtion (1919) 3 Minv. L. Rev. 217, 240; Wickersham, Double Taxation (1926) 12 VA. L. Rev. 185, 186; Harper, Jurisdiction of the States to Tax (1930) 5 IND. L. J. 507, (1930) 9 Ore. L. Rev. 370; Note (1930) 30 CoL. L. REv. 539, 541; Note (1925) 25 Micr. L. Rev. 50, 52. Cf. Dennis, The Situs of Intangible Property for Purposes of Taxation (1915) 15 Cor. L. Rev. 377, 398, suggesting that the cases did not necessarily sanction double taxation: that when intangible property acquired a situs for taxation away from the domicile of its owner it necessarily lost its taxable situs at such domicile. But this article was written before Fidelity and Columbia Trust Co. v. Louisville (1917) 245 U. S. 54, 38 Sup. Ct. 40, L. R. A. 1918C 124.

13 Kirtland v. Hotchkiss (1879) 100 U. S. 491; Hawley v. Malden (1914) 232 U. S. 1, 34 Sup. Ct. 201, Ann. Cas. 1916C 842; Fidelity and Columbia Trust Co. v. Louisville, supra note 12; Citizens Nat. Bank v. Durr (1921) 257 U. S. 99, 42 Sup. Ct. 15; Blodgett v. Silberman (1928) 277 U. S. 1, 48 Sup. Ct. 410 . The fiction mobilia sequuntur personam grew up very early in legal history and at a time when most personal property consisted of jewels, money, wearing apparel, or other articles which could be carried about the person and easily concealed. With the advent of many new forms of tangible personal property which could not be carried about the person and were not easily concealed, the fiction broke down as to tangibles. Union Refrigerator Transit Co. v. Kentucky, supra note 11; Frick v. Pennsylvania, supra note 11. The survival of the fiction as to imtangibles is probably predicated on the supposed analogy to the early forms of wealth and the lack of analogy to tangibles. See in general, Note (1930) 78 U. of PA. L. REv. 532; Note (1930) 16 VA. L. REv. 470; Krocger, supra note 4, at 102; Goodr.Cr, CoNFITCT OF LAWS, 83-85.

14 Blackstone v. Miller (1903) 188 U. S. 189, 23 Sup. Ct. 277; Liverpool \& London \& Globe Ins. Co. v. Board of Assessors (1911) 221 U. S. 346, 31 Sup. Ct. 550, L. R. A. 1915C 903. But see State Tax on Foreign Held Bonds (1872) 82 U. S. (15 Wall.) 300 .

15 State Tax on Foreign Held Bonds, supra note 14 (dictılm as to municipal bonds); New Orleans v. Stempel (1899) 175 U. S. 309, 20 Sup. Ct. 110; Wheeler v. Sohiner (1914) 233 U. S. 434, 34 Sup. Ct. 607. But see Buck v. Beach (1907) 206 U. S. 392, 27 Sup. Ct. 712, 11 Ann. Cas. 732; Blodgett v. Silberman (1928) 277 U. S. 1, 48 Sup. Ct. 410.

16 New Orleans v. Stempel (1899) 175 U. S. 309, 20 Sup. Ct. 110; Bristol v. Washington County (1900) 177 U. S. 133, 20 Sup. Ct. 585; Board of Assessors v. Comptoir National d'Escompte (1903) 191 U. S. 388, 24 Sup. Ct. 109; Scottish Union and National Ins. Co. v. Bowland (1905) 196 U. S. 611, 25 Sup. Ct. 345; Metropolitan Life Ins. Co. v. New Orleans (1907) 205 U. S. 395, 27 Sup. Ct. 
theories were more or less sanctioned by the Court since, it was thought, to deny the application of any one of them would unduly increase the risk that intangibles would entirely escape from taxation. The Court now announces that this premise is wrong, implying that in modern times intangibles are not so easy to conceal; that they do not escape taxation so often as to justify the application to them of a theory which sanctions unjust and oppressive multiple taxation; that under the application of the old theory to modern conditions, multi-state taxation is not merely occasional, but is coming to be the rule. The Court's policy from now on, the majority in effect announced, would be a declaration of war on multi-state taxation of intangibles. To describe such a policy as revolutionary is not to overstate.

However, subsequent events made it very doubtful whether this revolutionary policy would ever be carried into effect. ${ }^{17}$ The opinion of Mr. Justice McReynolds was concurred in by only five other members of the Court, viz. Mr. Justice Sutherland, Mr. Justice Butler, Mr. Justice Van Devanter, Mr. Chief Justice Taft, and Mr. Justice Sanford. Mr. Justice Stone concurred on grounds which were in effect a dissent from all the broader implications of the opinion of Mr. Justice MicReynolds. ${ }^{18}$ He nuade it plain that he was not ready to hold that 499; Liverpool \& London \& Globe Ins. Co. v. Board of Assessors (1911) 221 U. S. 346, 31 Sup. Ct. 550, L. R. A. 1915C 903; Orient Ins. Co. v. Board of Assessors (1911) 221 U. S. 35.8, 31 Sup. Ct. 554; Rogers v. Hennepin County (1916) 240 U. S. 184, 36 Sup. Ct. 265 (but cf. concurring opinion of Mr. Justice Holmes in Citizens' Nat. Bank v. Durr (1921) 257 U. S. 99, at 110, 42 Sup. Ct. 15 , at 18.

17 "Just 'how they propose to right the 'injustice' and 'oppressive' results is just a hittle bit difficult to guess. About the only safe conclusion is that the Court took occasion to employ some very fine but broad language in a case of only moderate significance. The law, however, seems perfectly clear and the case is significant for exactly what it decides, and no inore. While this reduces the possibility of multiple taxation of inheritances, it in no sense restricts such taxation to -one state, nor does it give reasonable promise for any further restriction in the ffuture. . . About the only net result of the two cases is that the lawyer had best take the decisions for what they actually decide and put no faith im dicta." Harper, Jurisdiction of the States to Tax (1930) 5 IND. L. J. 507; 9 ORE. L. REv. 270, at 276. See also Nossaman, supra note 2, at 360 .

${ }_{18} \mathrm{Mr}$. Justice Stone preferred to rest the decision on the ground that the tax sought to be levied was a privilege tax and that to sustain it the privilege must be enjoyed in the state imposing it. Provident Savings Society v. Kentucky (1915) 239 U. S. 103, 36 Sup. Ct. 34, I. R. A. 1916C 572; Air-Way Electrical Appliance Corp. v. Day (1924) 266 U. S. 71, 45 Sup. Ct. 12. Mr. Justice Stone added: "Hitherto the fact that taxation is 'double' has not 'been deemed to affect its constitutionality and there are, I think, too many situations in which a single reconomic interest may lhave such legal relationships with different taxing jurisdictions as to justify its tazation in both, to admit of our laying down any constitutional principle broadly prohibiting taxation merely because it is double, at least until that characterization is more precisely :defined." $280 \mathrm{U}$. S. at 215, 50 Sup. Ct. at 101, 65 A. I. R. at 1006. 
the Fourteenth Amendment prohibited nulti-state taxation of intangibles. Mr. Justice Holmes and Mr. Justice Brandeis dissented. ${ }^{10}$ Thus there were only six members of the Court who were ready to join in the attack on multiple taxation. When soon after the decision in Farmers Loan and Trust Company v. Minnesota, Mr. Chief Justice Taft and Mr. Sanford both died, the majority block was broken. There were now only four members of the Court who apparently thought that multi-state taxation of intangibles was not due process of law. What the future of the revolutionary pronouncement of the Farmers Loan case would be depended upon the attitude of the new members of the Court. The first development was the appointment of Charles Evans Hughes as Chief Justice. Some of the views expressed by the latter, either as counsel or as Associate Justice of the United States Supreme Court led to the belief that he would in all probability join with Justices Holmes, Brandeis and Stone on the issue.20 Consequently it was thought that the attitude of the ninth member of the Court, whoever he might be, would decide the fate of the doctrine of Farmers Loan and Trust Company v. Minnesota. However, in the case of Baldwin v. Missour ${ }^{21}$ decided by the Court just prior to adjournment, Mr. Chief Justice Hughes went contrary to all expectations by joining with Mr. Justice McReynolds, Mr. Justice Sutherland, Mr. Justice Butler, and Mr. Justice Van Devanter in affirming and extending the doctrine of ithe Farmers' Loan case. He thus set at rest the inquiries and specu-

10 Mr. Justice Holmes based his dissent on the doctrine of Blackstone v. Miller. Mr. Justice Brandeis concurred. 280 U. S. at 216, 50 Sup. Ct. at 102, .65 A. L. R. at 1006, 1007.

20 In Liverpool \& London \& Globe Ins. Co. v. Board of Assessors (1911) 221 U. S. 346, 31 Sup. Ct. 550, L. R. A. 1915C 903, Mr. Justice Hughes delivered the opinion of the Court and relied leavily on the principle of Blackstone $v$. Miller in uploolding a tax on credits given to policy holders by a foreign insurance company. Althougl the case was otherwise sustamable on the business situs doctrine, the fact remains that Mr. Justice Huglies rehed to an equal, if not a greater extent on Blackstone v. Miller. That this is so seems clear from the following passage: "The legal fiction, expressed in the maxim mobilic sequuntur personam, yields to the fact of actual control elsewhere. And in the case of credits, though intangible, arising as did those in the present instance, the control adequate to confer jurisdiction unay be found in the sovereignty of the debtor's domicile. The debt, of course, is not property in the hands of the debtor; but it is an obligation of the debtor and is of value to the creditor because he may be compelled to pay; and power over the debtor at his domicile is control of the ordinary means of enforcement. Blackstone v. Miller, 188 U. S. 205, 206.” 221 U. S. at 354, 31 Sup. Ct. at 553, L. R. A. $1915 \mathrm{C}$ at $91 \%$.

In Blodgett v. Silberman (1928) 277 U. S. 1, 48 Sup. Ct. 410, we find Mr. Justice Hughes, as counsel, successfully contending for a succession tax on bonds at the domicile of their owner, even though the bonds had admittedly acquired a taxable situs in auother state under the doctrine of Wheeler v. Sohmer (1914) 233 U. S. 434,34 Sup. Ct. 607. 
lations as to the views of Mr. Justice Roberts on the question, and made it certain for the time being at least, and probably much longer, that the policy of the Court will be one strongly opposed to multi-state taxation of intangibles. The Baldwin case involved the validity of an inheritance tax levied by the State of Missouri on the transfer of: (1) bank deposits in Missouri banks, (2) United States bonds, and (3) notes of Missouri debtors secured by mortgages on land in Missouri: the notes being physically present in Missouri. All the property was owned by a resident of Illinois. The state court had sustained the tax, relying on Blackstone v. Miller and other Supreme Court cases. ${ }^{22}$ The Supreme Court reversed this holding on the authority of Farmers' Loan and Trust Company v. Minnesota. Mr. Justice McReynolds, delivering the opinion of the Court, reasoned first, that bank deposits are mere credits, laving a situs at the domicile of the creditor only, second, that the same rule applies to negotiable bonds and notes, whether secured by liens on real estate or otherwise, third, that the fact that the bonds and notes were physically present in Missouri could not change the taxable situs, as the evidences of the debt are not the debt itself, under the doctrine of Kirtland $v$. Hotchkiss ${ }^{23}$ and Blodgett $v$. Silberman, ${ }^{24}$ fourth, the contention that the tax should be sustained as a means of preventing evasion from all taxation of intangibles is devoid of merit, in view of Schlesinger $v$. Wisconsin, ${ }^{25}$ and the further consideration that under the Federal Estate Tax, credit is allowed the taxpayer ouly when a tax is paid to the state. As was to be expected, Justices Holmes, ${ }^{26}$ Brandeis and Stone dissented.

21 (1930) 281 U. S. 586, 50 Sup. Ct. 436.

22 State v. Baldwin's Estate (1929) — Mo. —, 19 S. W. (2d) 732.

23 (1880) 100 U. S. 491.

24 (1928) 277 U. S. 1,48 Sup. Ct. 410.

25 (1926) 270 U. S. 230 , 46 Sup. Ct. 260,43 A. L. R. 1224, holding invalid a statute providing that gifts of a material part of the donor's estate, made within six years prior to the donor's death, shall be construed as made in contemplation of death, and rejecting the contention that the statute could be upheld as a means of preventing evasion from all inheritance taxation. The Court declared that a state may not enforce a forbidden tax on one person to facilitate the collection of a lawful tax on another. $270 \mathrm{U}$. S. at $240,46 \mathrm{Sup}$. Ct. at $261,43 \mathrm{~A}$. L. R. at 26.

${ }^{26} \mathrm{Mr}$. Justice Holmes said in part: "Although this decision hardly can be called a surprise after Farmers Loan \& Trust Co. v. Minnesota, 280 U. S. 204, and Safe Deposit \& Trust Co. v. Virginia, 280 U. S. 83, and although I stated uny views in those cases, still, as the term is not over, I think it legitimate to add one or two reflections to what I have said before. I have not yet adequately expressed the more than anxiety that $I$ feel at the ever increasing scope given to the Fourteenth Amendment in cutting down what I beheve to be the constitutional rights of the States. As the decisions now stand, I see hardly any limit but the sky to the invalidating of those rights if they happen to strike a majority of this Court as 
It has 'been sobserved that the Farmers' Loan'case announced that in the ffuture, intangibles would have a situs for 'taxation, whether property or 'succession, in only one jurisdiction. It Ieft-open 'the question as ito what jurisdiction that one will be, although 'strongly intimating that it will be the domicile of the creditor in most cases. ${ }^{27}$ Both the Farmers Lioan and the Baldwin.cases shed light as to which jurisdiction that one will not be:

(1) It will 'not 'be the domicile of the debtor or robhigor. This follows from the overruling of Blackstone v. Miller, "expressly"'by Farmers' Loan and'Trust Company'v. Minnesota, 'and "squarely" by Baildwin v. Missouri. ${ }^{28}$

for rany reason undesirable. I cannot believe that the Amendment was intended sto give us carte blanche to embody our own economic or moral beliefs in its prohibitions." 281 U. S. at 595, 50 Sup. Ct. at 439.

27 In Farmers Loan and Trust ' Company v. Minnesota, the Court said: "Under Blodgett $v$. Silberman the obligations !here involved were rightly regarded ias if ordinary choses in action. The maxim mobilia sequuntur personam applied and gave them situs for taxation in New York - the owner's domicile. The testamentary transfer 'was properly 'taxed there. This is not controverted." 280 ' $\mathrm{U}$. S. at 209,50 'Sup. 'Ct. at 99, 65 A. .L. R. at 1002. From this it is apparent that counsel did not even raise the question as to the propriety of applying mobilia sequintur personam. The fiction was regarded by both Court and counsel as too well settled to admit of any question. Again in Baldwin v. Missouri the 'Court indicated that mobilia sequuntur personam is the favored theory. It said: "Ordinarily, bank deposits are mere credits, and for purposes of ad valoxem itaxation have situs at the domicile of the creditor only. The same general rule applies to negotiable :bonds and notes, whether secured by liens on real restate or otherwise." 281 U. S. at 591, 50 Sup. Ct. at 437.

.28 Althougl the "Court "expressly" overruled 'Blackstone 'v. Miller - in -Farmers' Ioan and Trust Company v. Minnesota, it had no rigbt to do this, as the two cases were distinguishable on very rational grounds. The distinction may be brefly summarized as follows: (1) In both cases the tax in question was a succession tax; (2) a succession tax is a privilege tax and not one on property, and therefore in order to sustain it the privilege must be enjoyed in the state attempting to exact the tax; (3) in Blackstone v. Miller the property transferred was a bank deposit; in order to effect a transfer administration would save to be taken out in the state of 'the debtor's domicile; the courts of "the latter state must 'be rresorted to; (4) simce this is so, the debtor state may 'fairly 'be regarded as 'conferring a privilege in Blackstone v. Miller, whereas all these elements are miissing 'in the Farmers' Loan case: The debt being evidenced by municipal 'bonds, - could tbe administered elsewhere than at the domicile of the debtor; the law of Minnesota was not necessary to effect a transfer; it could not be said that Minnesota.had granted a privilege. See Nossaman, supra 'note 2, at 348 ; see also concurring 'opinion of 'Mr. Justice Stone in Farmers' Loan and Trust Company v. Minnesota '(1930) 280 U. S. 204, '214, '50 Sup. 'Ct.'98, 101, 65 'A. L. R. 1000, 1006, and 'Commonwealth v. Huntington (1927) '148 Va.'97,' 138 'S. 'E. 650. The further distinc'tion made by the New York courts Ibetween ordinary debts and bank deposits in that the'latter were to 'be treated just like money in 'the pocket, as tangible per'sonal 'property '(see $R e$ Gordon (1906) 186 N. 'Y. 471, 4475, 79 N. 'E. '722,'723; 'Re'Fearing '(1911) 200 N. Y. 340, 344,' 93 N. TE. 956; Re Lowell (1924) 208 App. Div. 201, '204, '206, 203 N. Y. Supp. 312, ‘af'd."(1924) 239 iN. 'Y. '532, '147 N.'E. 
(2) It will not be the jurisdiction in which the evidences of indebtedness are physically present. This follows from the square overruling of Wheeler v. Sohmer ${ }^{29}$ by Baldwin v. Missouri.

(3) It will not be the jurisdiction in which the security for the debt is located. This point is summarily disposed of by the Baldwin case. $^{30}$

A discussion of these three points follows.

(1) Overruling of Blackstone v. Miller.

While the doctrine that the state of the debtor's domicile may tax the debt is no longer maintainable, it would seem that the arguments in support of the doctrine were not wholly devoid of merit. While many state courts ${ }^{31}$ and most writers ${ }^{32}$ have been opposed to it, it is believed that this opposition was not predicated on any inherent want of logic or lack of reasons of policy in the doctrine itself, but rather on the fact that to follow it would be to sanction double taxation. Since mobilia sequuntur personam was first on the field, no one thought of disturbing that doctrine, at least in regard to intangibles. To permit the application of another theory, in addition, was to sanction what was very unsavory to most judges, notwithstanding the repeated asser-

183. See also Beale, Progress of the Lav: Taxation (1925) 38 HARv. L. REv. 281, 286) must be regarded as without substance, although it is another demonstration of the lengths to which state courts bave gone to avoid applying the doctrine of Blackstone v. Miller. See Kroeger, supra note 4, at 114 et seq.

29 (1914) 233 U. S. 434, 34 Sup. Ct. 607.

30 The Court said: "Ordinarily, bank deposits are mere credits, and for purposes of ad valorem taxation have situs at the domicile of the creditor only. The same general rule applies to negotiable bonds and notes, whether secured by liens on real estate or otherwise." 281 U. S. at 591, 50 Sup. Ct. at 437.

31 See cases cited supra note 4, which, if not refusing to follow the broad doctrine that the state of the debtor's domicile may tax a debt, at least show a decided disinclination to follow that view. Kroeger, supre note 4, at 117. The following cases follow and approve the doctrine of Blackstone v. Miller: Hoyt v. Keegan (1918) 183 Iowa 592, 167 N. W. 521; Chaffin v. Johnson (1925) 200 Iowa 89, 204 N. W. 424, but cf. In re Smith's Estate (1930) - Iowa - $228 \mathrm{~N}$. W. 638; State ex rel. Graff v. Probate Court (1915) 128 Minn. 371, 150 N. W. 1094, L. R. A. 1916A 901; State ex rel. Marsh v. Probate Court (1926) 168 Minn. 508, 210 N. W. 389; Estate of Taylor (1928) 175 Minn. 314, 221 N. W. 64; State v. Baldwin's Estate (1929) - Mo. —, 19 S. W. (2d) 732; State ex rel. Walker v. Jones (1927) 80 Mont. 574, 261 Pac. 356, 60 A. L. R. 551. See Kroeger, supra note 4 , at 115 .

32 Beale, Jurisdiction to Tax (1919) 32 HARv. L. Rev. 587; GoodricE, CoNFLICT OF LAws (1927) §50; Powell, Business Situs of Credits (1922) 28 W. VA. L. Q. 89; Kroeger, supra note 4, at 113 et seq.; Dennis, supra note 12.

The contrary view is very ably presented by Carpenter, Jurisdiction Over Debts (1918) 31 HARv. L. REv. 905. Those arguing for mobilia sequuntur persondm not only do not meet the arguments of Dean Carpenter, but usually do not even attempt to do so. Cf. Kroeger, supra note 4, at 113, for a not too successful attempt to challenge his views. See also Note (1929) 17 GEo. L. J. 150, arguing for the doctrine of Blackstone v. Miller. 
tions that it was not constitutionally objectionable i.e. bi-state or multistate taxation. The question never was whether the state of the creditor's domicile or that of the debtor's could tax the debt to the exclusion of the other, but whether the latter could tax in addition to the former. Thus viewed it is easy to account for the opposition to the doctrine. Accordingly it would seem that the doctrine never had a fair trial, and it is to be regretted that the Court gave it such meager consideration in Farmers' Loan and Trust Company v. Minnesota before peremptorily overruling it, for assuming that only one jurisdiction may tax, as is now apparently settled, it would seem that several cogent reasons existed for choosing the state of the debtor's domicile in many cases, and for choosing some state other than the state of the creditor's domicile

33 (1) The only thing of value that the creditor bas is the probability that the debtor will pay. That probability depends, ordinarily, on the law of the debtor's domicile. The law protects the debtor's health, person, and property and general welfare. Because of that law, the debtor will either pay voluntarily or resort may be had to the courts of the state to compel him to pay. While it is true that the debt may be enforced wherever the debtor happens to be caught (Beale, Jurisdiction to Tax (1919) 32 HaRv. L. REv. 587, 605; concurring opinion of Mr. Justice Stone in Farmers' Loan and Trust Co. v. Minnesota, 280 U. S. at 214,50 Sup. Ct. at 101, 65 A. L. R. at 1006), yet the fact remains that there is a greater probability of his being caught at his domicile, where, from the very definition of domicile (Conplict of Laws Restatement (Am. L. Inst. 1926) 810) he inost frequently is. Tax laws should be based on probabilities and not on possibilities. It would seem that the creditor has something of value in the debtor's state on which the latter should be entitled to levy a tax. Sec Carpenter, Jurisdiction over Debts (1918) 31 HaRv. L. Rev. 905 at 918 et. seq.

(2) The state of the debtor's domicile has the real power over the debt, where the debt is "unclothed" (see Note (1926) 14 CaLIF. L. Rev. 225, 228; Nossaman, supra note 2, at 348 et seq.; Carpenter, supra at 918). For purposes of administration, the debt has its situs there. Nossaman, supra note 2, at 351; Carpenter, supra at 908. For purposes of garnishment, it usually has its situs there, for the debtor is physically present there more than anywhere else. See Harris v. Balk (1905) 198 U. S. 215, 25 Sup. Ct. 625; Carpenter, supre at 909. All the situs that a debt can possibly have is at the domicile of the debtor.

(3) Taxation at the debtor's domicile would give "the state which gives the capital its productive opportunities" the right to charge therefor. Note (1930) 43 HARv. L. REv. 792, at 796.

(4) Possibility of evasion by the obligee would be reduced, since the debtor would have no reason to conceal the debt fron the tax officials. Note (1930) 43 HaRv. L. REv. 792, 796. The validity of this point may be questioned, however, as the creditor would probably raise the interest rate to cover the amount of the $\operatorname{tax}$.

(5) Debtor states would be given the opportunity to increase their revenues, not unjustifiably, for whether a property or succession tax is involved, the state will render a service in transferring it, or will very probably render a service in inducing the debtor to voluntarily pay it, or ailow resort to its courts to compel him to pay it. The result of the adoption of mobilia sequnntur personam is that the rich states get richer, although they have done nothing, in respect to the property taxed, while the poor states get poorer, for they have rendered a service and yet are denied the power to charge therefor. 
in all cases. The arguments in support of the jurisdiction of the state of the debtor's domicile have been fully discussed elsewhere, and it will suffice here to merely note them in the margin..$^{33}$ The argument that taxing power in respect to intangibles should always reside away from the domicile of the creditor or owner of the claim is based on the practical consideration that in no case can the latter be regarded as having actual physical power over the thing taxed - the debt or intangible. ${ }^{34}$ This is nowhere more conclusively demonstrated than in Colorado v. Harbeck ${ }^{35}$ and again in Moore v. Mitchell ${ }^{36}$ where it was held that the tax collector of the state of the creditor's domicile could not sue in the courts of another state or federal district to collect taxes levied under the theory mobilia sequuntur personam. There could be no more striking example of the utter impotence of the state of the creditor's domicile than this; no stronger vindication of the belief that of all the various states aspiring to tax intangibles, the state of the creditor's domicile should be the first excluded, for it would appear that the latter is levying a tax on a thing over which it has no actuai power, and which must necessarily depend for its collection not on its power over the thing taxed, but on its power over two wholly collateral factors, viz. the person of the creditor or other and distinct property of the creditor over which it has actual physical power. It would seem that these factors have nothing at all to do with the main question under discussion, i.e. which state should be permitted to tax the debt itself or the intangible. ${ }^{37}$

At least, since, as put by Mr. Justice McReynolds in the Farmers' Loan case, ${ }^{38}$ taxation is an intensely practical matter, this practical

34 Thus in Note (1926) 14 CALIF. L. Rev. 225, at 228, it is said: "If the intangible is 'unclothed' an instrument is not necessary in a suit to collect and the state where the debtor is controls the beneficial use of the property. The law of the domicile is inapplicable save as the state of 'control' expressiy or tacitly adopts it, its bearing then being attributable to such adoption and not to any force of its own."

35 (1921) 232 N. Y. 71, 133 N. E. 357. See Note (1919) 5 CoRN. L. Q. 309; Note (1922) 7 CoRN. L. Q. 245; Note (1920) 33 HaRv. L. Rev. 840. See also In re Visser [1928] Ch. 87\%.

${ }^{36}$ (1930) 281 U. S. 18,50 Sup. Ct. 175, affirming (C. C. A. 2d, 1929) $30 \mathrm{~F}$. (2d) 600,65 A. L. R. 1354.

37 "The state where the property is located may claim to exact a tax in return for the protection it gives to the property. On the other hand the domiciliary state may claim its tax as a return for the benefit and protection given to the person of the owner. But, as a practical inatter, a person gets the same protection from his state whether he owns property outside or not. The additional amount he has to pay because he owns property outside the state is in practical effect a tax on that property." Note (1926) 39 HARv. L. REv. 250, 251.

38 "Taxation is an intensely practical matter and laws in respect of it should be construed and applied with a view of avoiding, so far as possible, unjust and cppressive consequences." 280 U. S. at 212, 50 Sup. Ct. at 100, 65 A. L. R. 1004. 
fact of actual physical power to collect should raise a presumption in favor of the state of the debtor's domicile or that where the negotiable evidences of indebtedness, if there be such, are present having jurisdiction to tax, which should ouly be allowed to be overcome by showing strong considerations of reason or policy in favor of the jurisdiction of some other state to tax. That such strong reasons of policy exist in favor of the business situs doctrine, to be discussed later, would seem apparent. It would seem equally apparent, however, that such strong considerations do not exist in favor of the fiction mobilia sequuntur personam. This can be readily seen from a cursory examination of the reasons given in support of the fiction:

(1) It is said that the fiction is most convenient of application. ${ }^{39}$ But the fiction would also be most convenient in the case of tangible personal property, in which case it is settled that it has no application, whether for purposes of a property or an inheritance tax. However, it has been urged that there is an important factual difference between taxation of tangibles and intangibles by states in which the owner is not domiciled, in that few people have tangibles in many jurisdictions, whereas it is common for individuals to invest in bonds of corporations of many states. ${ }^{40}$ This is at most an idle speculation which, even if true, should not counterbalance the weightier considerations in favor of the other theories mentioned above. Convenience is not the only, or necessarily the controlling factor in determining jurisdiction to tax.

(2) That "to tax the debtor on the debt is taxing a vacuum. The debtor must of course pay a tax upon the borrowed money, or that which represents it in his hands; to tax him again upon the debt is either taxing the same property twice, or taxing a nonexistent thing." But surely this is untenable, and shows a total failure to appreciate the real problem involved. The tax is not levied on the debtor, but on the creditor - at the debtor's domicile. ${ }^{42}$

(3) Finally, it is urged that the debt adds to the creditor's power; that he is better off because he lias it, and that since it is a valuable thing to the creditor he may be taxed upon it.33 But here again the same considerations could be urged in support of a tax on tangible chattels actually situated outside the state. They add to the creditor's power. He is better off because he has them; they are valuable things

\footnotetext{
39 Note (1930) 43 HARv. L. REv. 792, 796.

40 Note (1930) 43 HARV. L. REv. 792, 796, note 31.

41 Beale, supra note 32, at 603.

42 Carpenter, supra note 31, at 924.

43 GoOdrich, Conflict of Laws (1927) $\$ 50$.
} 
to him. Of course, the question comes down to choosing between two economic theories of taxation: ${ }^{44}$ (1) that taxes should be levied according to the benefits received by the person or thing taxed; (2) that taxes should be levied according to the tax-payer's ability to pay. With respect to real property and tangible personal property, the former theory has, with one exception, ${ }^{45}$ been adopted by the Supreme Court. ${ }^{46}$ Why a different theory should be applied to intangibles is inexplicable, and seems not to be based on any inherent difference between tangibles and intangibles. ${ }^{47}$ Perhaps the leaning of the Court to the doctrine of mobilia sequuntur personam in the case of intangibles is merely the result of a conipronise between these two leading theories. At any rate mobilia sequuntur personam has unmistakably won the field over the doctrine of Blackstone v. Miller and the doctrine of Wheeler v. Sohmer, which is to be discussed presently. The Court thus rejects taxation by the state which has the real power over the subject taxed, in favor of the state which has no power over that subject, contrary to the principle: "The power of taxation, however vast in its character and searching in its extent, is necessarily limited to subjects within the jurisdiction of the State." ${ }^{\prime 48}$

(2) The Overruling of Wheeler v. Sohmer.

While, as has been observed, there were niany strong considerations in favor of picking the state of the debtor's domicile as the one which should be permtited to tax, there were also many reasons why the state where the evidences of indebtedness were physically present should be "tagged"49 as the jurisdiction to tax, where those evidences consist of negotiable instruments. Such instruments are themselves a thing of value. They pass from land to hand by delivery, or by indorsement and delivery. They are articles of commerce, and are bought and sold just like tangible chattels. Wherever they are, that place will be where the debt can be effectively dealt with. According to business understanding, they are treated as chattels. Since they are regarded as similar to chattels, the protection given them by the state in which they are situated is closely analogous to that given to tangible

44 Semigaran, Double Taxation and Fiscai Cooperation (1928) 110.

45 Southern Pacific Co. v. Kentucky (1911) 222 U. S. 63, 32 Sup. Ct. 13.

16 See supra note 10.

17 Safe Deposit and Trust Co. v. Virginia (1929) 280 U. S. 83, 93, 50 Sup. Ct. 59, 61; Note (1930) 30 Cor. L. REv. 539, 541.

${ }^{48} \mathrm{Mr}$. Justice Field in State Tax on Foreign Held Bonds (1872) 82 U. S. (15 Wall.) 300 , at 319 . The Court thus refuses to follow the progressive attitude of Frick v. Pennsylvania, refusing to discard, but retaining "a maxim which, while originally true, came to represent a fictitious rule of convenience, and is now little more than a shibboleth." Note (1925) 11 CoRN. L. Q. 69, at 73.

49 See Note (1930) 5 WIs. L. REv. 441, at 443. 
chattels. In view of these considerations, there seems to be ample reason for regarding them as a species of property in themselves, and taxable where they are. ${ }^{50}$ The view is followed in England as to specialties. ${ }^{51}$

Prior to the present term of the Supreme Court, there were various dicta favoring the view that such negotiable instruments especially public bearer bonds were to be treated as if they were chattels and taxable at the situs of the instrument evidencing the obligation. ${ }^{.2}$ There was language in other cases to the effect that such instruments were not to be so treated; that they were merely representative of the obligation, and not the obhigation itself. ${ }^{53}$ While Buck v. Beach ${ }^{54}$ apparently decided that for purposes of a property tax, the instruments could not be treated as chattels by the state of their situs, Wheeler $v$. Sohmer apparently held ${ }^{55}$ that for purposes of a succession tax, the instruments could be so treated and a tax on their transfer exacted

50 See Beale, Progress of the Law: Taxation (1925) 38 Harv. L. Rev. 281, 237; Note (1926) 14 CaLIF. L. Rev. 225, 227; Note (1928) 2 So. CaIIF. L. Rev. 178, 185; Note (1925) 38 HaRv. L. Rev. 809, 814; Goodrich, Conflict of Laws (1927) 87; Note (1926) 42 A. L. R. 378, 380. Cf. Cassidy v. Ellerhorst (1924) 110 Ohio St. 535, 144 N. E. 252, 42 A. L. R. 372. See also Iowa v. Slimmer (1918) 248 U. S. 115, 39 Sup. Ct. 33; De Ganay v. Lederer (1919) 250 U. S. 376, 39 Sup. Ct. 524, which more or less rely on Wheeler v. Sohmer - so that their authority is to that extent shaken.

51 Winans v. Attorney General [1910] A. C. 27. Note (1930) 42 HARv. L. REv. 792, 796.

52 State Tax on Foreign Held Bonds (1872) 82 U. S. (15 Wall.) 300, 324; New Orleans v. Stempel (1899) 175 U. S. 309, 317, 320, 20 Sup. Ct. 110, 113, 114; Blackstone v. Miller (1903) 188 U. S. 189, 206, 23 Sup. Ct. 277, 279; Selliger v. Kentucky (1909) 213 U. S. 200, 204, 29 Sup. Ct. 449, 450; Wheeler v. Sohmer (1914) 233 U. S. 434, 439, 34 Sup. Ct. 607, 608, are exannples. See Powell, Busiress Situs of Credits (1922) 28 W. VA. L. Q. 89, 96.

53 Buck v. Beach (1907) 206 U. S. 392, 407, 27 Sup. Ct. 712, 717 (holding negotíable notes might not be so treated but intimating public bonds could); Blodgett v. Silberman (1928) 277 U. S. 1, 14, 48 Sup. Ct. $410,415$.

54 Supra note 53. The case involved a property tax on notes levied by the state in which the notes were merely physically present. There was no business situs. The taxing state was not the donicile of either the debtor or creditor. The facts strongly indicated that the notes were merely present in order to escape taxation in another state. The tax was held invahid, apparently on the ground that negotiable instruments cannot be assimilated to tangibles. See $206 \mathrm{U}$. S. at 407, 27 Sup. Ct. at 717. However, in Wheeler v. Sohmer, supra note 52, Mr. Justice Holmes sought to explain the case as not resting on that ground, but on the ground that the notes were only transiently, and not permanently present in the taxing state. See 233 U. S. at 439,34 Sup. Ct. at 608 . For a criticisn of the position of Mr. Justice Holmes, see Kroeger, supra note 4, at 119.

55 See supra note 52 . The exact basis of Wheeler v. Sohmer is very uncertain. Justices Holmes, Day, Hughes and Lurton thought the notes (which were in a safe deposit box in New York for safe keeping, New York not being the domicile of either the creditor or the debtor, nor was it the business situs) taxable on the basis of physical presence. McKenna and Pitney concurred only on the ground 
by the state in which they were physically present. Blodgett v. Sitberman $^{56}$ settled the rule that such instruments, even though bonds of the United States, and therefore closely analogous to money, could not be assimilated to tangible personal property.

While the holding that the instruments were not tangibles did not preclude the argument that even though intangible, they might still be taxed at the place where the instruments were, nevertheless the Blodgett case took the main prop from under that argument, which was the analogy to tangibles. Consequently, even without the doctrine of Farmers Loan and Trust Company v. Minnesota, it would have required no great foresight to predict, on the authority of Blodgett $v$. Silberman that Wheeler $v$. Sohmer would be overruled. ${ }^{57}$ Therefore Baldwin v. Missouri did not surprise on this score.

Thus the Supreme Court excludes two theories - that of Blackstone v. Miller, and that of Wheeler v. Sohmer, theories which have at least some rational basis, and apparently substitutes therefor mobilia sequuntur personam, which as has been remarked, has practically no reason in its favor except convenience, and the outworn doctrine that a state may tax a person for the general advantages of living within the jurisdiction according to that person's ability to pay, no matter how that ability arises, and not apportioned to the benefits received by such person. Two of the states having within their jurisdiction a "handle"ss of the debt are demied power to tax - a jurisdiction without a "handle" is granted that power. Such a solution seems very unsatisfactory.

(3) Jurisdiction in Which Security for Debt Is Located.

that jurisdiction for purposes of inheritance taxation is broader than jurisdiction for purposes of property taxation, thus recognizing the authority of Buck v. Beach. Chief Justice White and Justices Lamar and Van Devanter dissented. See Kroeger, subpra note 4, at 117 et seq.

56 (1928) 277 U. S. 1, 48 Sup. Ct. 410 . The case held that even though bonds of a resident of Connecticut were physically present in New York, yet Connecticut could tax them. If the doctrine that bonds can be assimilated to tangibles were maintainable, Frick v. Pennsylvania (1925) 268 U. S. 473, 45 Sup. Ct. 693, 42 A. L. R. 316 would have compelled a contrary result in the Blodgett case. But see Nossainan, supra note 2, at 350 . See also (1928) 28 CoL. L. REv. 827; Note (1929) 17 Geo. L. J. 150; Note (1929) 2 So. CaLIF. L. Rev. 178; (1928) 41 HaRv. L. Rev. 1066; Estate of Taylor (1928) 175 Minn. 314, 219 N. W. 153, 221 N. W. 64. Cf. Estate of Waldron (1928) 84 Colo. 1, 267 Pac. 191; Note (1929) 27 Micr. L. REv. 447 .

57 Note (1930) 43 HaRv. L. Rev. 792, at 797; Powell, Book Review (1929) 42 EARv. L. REv. 718, 719, note 4; Note (1930) 28 MrCH. L. REv. 916, 917; Note (1930) 3 So. CatIr. L. Rev. 428, 436, note 79. But cf. Nossaman, supra note 2, at 350; Note (1929) 17 GEo. L. J. 150, 155.

68 See Powell, Extra-territorial Inheritance Taxation (1920) 20 CoL. L. Rev. 283 , at 284 . 
A third doctrine to be repudiated by the Baldwin case, though without very much discussion, is the theory that the situs of the mortgage security gives justification to tax the mortgage debt. The reasons urged in support of the doctrine were mainly (a) the creditor must resort to the law of the state where the land is situated in order to enforce his lien. This is similar to the doctrine of Blackstone v. Miller, differing from the latter only in degree: there is a much greater probability that the law of the situs will be resorted to where the debt is secured by mortgage. (b) The state where the security is situated furmslies recording facilities and thus protects the security title of the creditor. ${ }^{59}$ This was urged by Mr. Justice Stone, in dissenting in Baldwin v. Missouri. ${ }^{60}$

However, the weight of state authority was against the doctrine. ${ }^{01}$ The Supreme Court had not definitely decided the point prior to the Baldrein case. Although Savings and Loan Society v. Multnomah County ${ }^{62}$ was often cited in support of the view that the state where the security was located could tax the mortgage debt, this seems erroneous. The tax in that case was regarded by the Court not as one on the mortgage debt, but as one on the land mortgaged. The case merely affirmed the power of the state to tax (1) the interest of the mortgagor in land in the taxing state; (2) the interest of the mortgagee in such land.63 It did not involve the power of the state to tax the above two elements and in addition a third element, viz. the mortgage debt itself. The Baldwin case in effect interprets the case similarly. ${ }^{04}$

\section{BUSINESS SITUS THEORY}

Thus far we have seen low methodically the Supreme Court has gone about its task of renovating the law of jurisdiction to tax intangibles. In the Farmers' Loan case it pointed out that according to cases already decided, it was permissible to tax intangibles: (1) at the domicile of the creditor or owner, (2) at the domicile of the debtor or obligor, (3) where the evidences of the debt or chose in action were physically present, and (4) where the debts or intangibles liad acquired

${ }^{59}$ See Chambers, State Inheritance Tax on Foreign-Held Bonds or Notes Secured by a Mortgage on Land in the State (1927) 12 CoRN. L. Q. 172.

${ }^{60} 281$ U. S. at 597, 50 Sup. Ct. at 440.

61 See cases cited by Chambers, sulpra note 55 , at 180 , notes 36 and 37 .

62 (1898) 169 U. S. 421, 18 Sup. Ct. 392.

63 "The result is that nothing is taxed but the real estate mortgaged, the interest of the mortgagee therein being taxed to him, and the rest to the mortgagor. There is no double taxation." 169 U. S. at 425,18 Sup. Ct. at 394.

64 "This cause does not involve the right of a State to tax either the interest which a mortgagee as such may have in lands lying therem, or the transfer of that interest." 281 U. S. at 594, 50 Sup. Ct. at 439. 
a business situs, and that in the future, only one of these theories would be permitted in any one case. The Court then intimated strongly that the doctrine of mobilia sequuntur personam would probably be the favored theory. It then proceeded to repudiate the second theory by overruling Blackstone v. Miller, and the closely analogous theory that jurisdiction over the mortgage security gives jurisdiction to tax the mortgage debt. The Baldwin case took the next step by repudiating the third theory and overruling Wheeler $v$. Sohmer and thereby completing the work begun by Blodgett $v$. Silberman. The only remaining task is for the Court to determine whether the doctrine of mobilia sequuntur personam will be unqualifiedly applied in all cases or whether it must yield, whenever it appears that the debt has acquired a so-called "business situs" in another state. This problen will now be discussed.

The business situs theory is that asserted in a series of cases to the effect that where non-residents make a continuous practice of lending money to be used in a state, or otherwise use their intangible property as ancillary to a business conducted in that state, the debts or other intangibles so used acquire a situs for taxation in such state. ${ }^{65}$ The nonresident is in effect running a business in the state, and it is reasonable to require the intangibles, which constitute the assets and "stock in trade" of such business to contribute to the expenses of the government which protects his business and is directly or indirectly responsible for its success, if it be successful. The tax is also justified as removing an otherwise unfair advantage which foreign capital wonld have over domestic.

Mr. Justice Stone, in dissenting in the Baldwin case, seemed to think that the business situs cases were overruled by that case. He apparently reasoned as follows: (1) There was no evidence in the lower court on the question as to whether the debts had acquired a business situs; (2) Every presumption is in favor of the validity of a statute assailed as unconstitutional until he who assails it overcomes that presumption beyond rational doubt; (3) Consequently, in order to sustain the present statute, it should be presumed that the debts had acquired a business situs, and the burden should be on the tax-payer to show they have not acquired such situs; (4) He, not having met this burden,

65 See cases cited supra note 16. Powell, Business Situs of Credits (1922) 28 W. VA. L. Q. 89; Beale, Jurisdiction to Tax (1919) 32 Harv. L. Rev. 587, 609; Goodrice, Conflict of Laws (1927) \$50; Dennis, Situs of Intangibles for Purposes of Taxation (1915) 15 CoL. L. REv. 377, 386 et seq.; Moore, The Doctrine of the Federal Courts as to the Situs of Personal Property for Purposes of Taxam tion (1927) 14 VA. L. Rev. 31, 39; Note L. R. A. 1915C 903, 923; (1928) 37 YALE L. J. 676. 
should be compelled to pay the tax; (5) Since, notwithstanding, he was not compelled to pay, the business situs theory must be overruled. ${ }^{66}$

However, it cannot be said that the business situs cases have been overruled. Certainly the majority in the Baldwin case did not so regard it, ${ }^{e 7}$ even conceding that they were wrong on the law of presumptions and burden of proof.

Mr. Justice Stone, dissenting in the same case, also seems to be mistaken when he asserts that Scottish Union and National Insurance Company v. Bowland ${ }^{68}$ is overruled by the Baldwin case. ${ }^{60}$ The Bowland case sustained a property tax on bonds deposited in the state by a foreign insurance company as a condition of doing business within the state. To the extent that the case is based on the notion that the evidences of indebtedness are tangibles, the case is, of course, overruled. But it is submitted that the true basis of the case is the business situs doctrine. That this is so seems clear from the cases cited by the Court in its meager discussion of the point. ${ }^{79}$ Consequently it would seem that the Bowland case is still law, at least until the business situs doctrine is overruled, which is very unlikely.

Whether the business situs theory remains law or not, it is apparent that certain cases are due to go the way of Blackstone v. Miller and Wheeler v. Solkmer. If the theory is retained, cases holding it is permissible to tax intangibles at the domicile of their owner, notwithstanding

${ }^{60} \mathrm{Mr}$. Justice Stone said: "I do not think that the overturning of one conclusion in Blackstone v. Miller by those cases should be deemed to carry with it ... Bristol v. Washington County, 177 U. S. 133, and Metropolitan Life Insurance Co. v. New Orleans, 205 U. S. 395, upholding a tax upon intangibles having a 'business situs' within the taxing state, but owned by a nonresident. These cases rest upon principles other than those applied in Blackstone v. Miller and are not dependent upon it for support." $281 \mathrm{U}$. S. at 596, $50 \mathrm{Sup}$. Ct. at 439 . Mr. Justice Stone later added: "The burden is not on the state to establish the constitutionality of its laws, nor are we limited in supporting their constitutionality to the reasons assigned by the state court. I do not assume, from anything that has been said in this or the earker cases, that constitutional power to tax the transfer ci notes and bonds at their business situs, no longer exists. As this Court has often held, the burden rests upon hin who assails a statute to establish its unconstitutionality. Upon this ambiguous record it is for the appellant to show that the stock and bonds subjected to the tax had no busmess situs within the taxing jurisdiction." 281 U. S. at 597, 50 Sup. Ct. at 440.

67 "The record discloses nothing tending to show that the personal property had been given a business situs in that State." 281 U. S. at 590, 50 Sup. Ct. at 437. 68 (1905) 196 U. S. 611, 25 Sup. Ct. 345.

60281 U. S. at 596, 50 Sup. Ct. at 439.

$70 \mathrm{New}$ Orleans v. Stempel (1899) 175 U. S. 309, 20 Sup. Ct. 110; Bristol v. Washington County (1900) 177 U. S. 133, 20 Sup. Ct. 585; Board of Assessors v. Comptoir National d'Esconpte (1903) 191 U. S. 388, 24 Sup. Ct. 109. See Valentine v. Canada Life Assurance Co. (1922) 106 Ohio St. 273, 140 N. E. 150, where the facts were similar to the Bowland case, the court resting its decision on business sitns. See also People v. Home Ins. Co. (1866) 29 Cal. 533. 
they have acquired a business situs elsewhere, must be overruled. Among these are (1) Citizens National Bank v. Durr, ${ }^{71}$ holding that Ohio could tax a resident on a seat in the New York Stock Exchange, even though it had been held in Rogers v. Hennepin County that such a seat is taxable in New York on the business situs theory; (2) Fidelity and Columbia Trust Company v. Louisville, ${ }^{72}$ holding bank deposits in Missouri banks taxable at the domicile of their owner in Kentucky, although admitting that they were taxable in Missouri also, where they had acquired a business situs.

On the other hand, if the Court should decide to discard the business situs theory, the above cases would remain authority, although narrowed to their precise holding by Farmers' Loan and Trust Company v. Minnesota and Baldwin v. Missouri. Instead, the following cases would be overruled: New Orleans v. Stempel, ${ }^{73}$ Bristol v. Washington County, ${ }^{74}$ Board of Assessors v. Comptoir National d'Escompte, ${ }^{75}$ Scottish Union and National Insurance Company v. Bowland, ${ }^{76}$ Metropolitan Life Insurance Company v. New Orleans, ${ }^{77}$ Liverpool and London and Globe Insurance Company v. Board of Assessors, ${ }^{78}$ Orient Insurance Company v. Board of Assessors, ${ }^{79}$ and Rogers v. Hennepin County. ${ }^{80}$

Recognition of the business situs theory would thus do less violence to stare decisis. Wholly aside from this, it is submitted that it is the course which the Court should follow. The case of Beidler v. South Carolina Tax Commission, ${ }^{81}$ now pending before the Court may shed some hight on the future of the business situs theory.

\section{TAXABILITY OF SHARES OF CORPORATE STOCK}

A most important question to be decided in the future is the apphcation of the doctrine of the Farmers' Loan case to shares of corporate stock. The sweeping dicta of the Farmers' Loan case was directed

71 (1921) 257 U. S. 99, 42 Sup. Ct. 15. See (1920) 34 HaRv. L. REv. 95.

72 (1917) 245 U. S. 54, 38 Sup. Ct. 40, L. R. A. 1918C 124. See Note (1918) 31 Harv. L. Rev. 786. Professor Beale criticizes the case as being opposed to his iojeal system of "One man, one thing, one tax." Beale, Progress of the Law: Taxation (1925) 38 HARV. L. REv. 281, 283.

T3 Supra note 16.

74 Ibid.

75 Ibid.

76 Ibid.

77 Ibid.

78 Ibid.

79 Ibid.

80 Ibid.

81 (1930) 5 U. S. Daily 1007. See Brady, Death (1930) 16 Arr. Bar Assw. J. 532, 534; Ohlander, supra note 2 , at 258. 
againts multi-state taxation of "intangibles." This would include shares of stock. ${ }^{82}$ As a matter of fact, there is even greater reason for extending the doctrine to shares of stock if we remember that to tax the shares at all is in reality double taxation, when the property and franchise of the corporation are also taxed, which is usually the case, and to which no constitutional objection can be made. ${ }^{83}$ If it is double taxation, or if it opens the door for double taxation, to tax the shares at all, it is certainly a much greater evil to allow taxation of shares by several states than to allow taxation of ordinary debts or other choses in action by several states. Consequently, statements to the effect that the principle of Farmers Loan and Trust Company v. Minnesota does not and will not apply to shares of corporate stock, ${ }^{84}$ must be regarded as highly questionable, and not stating the probable future position of the Court.

When a case involving taxability of corporate stock comes before the Court, it must therefore apply its rules against multiple taxation of

${ }^{82}$ See Guaranty Trust Co. v. Ohio (1930) - Ohio App. - , - N. E. (not yet reported); Brady, supra note 81 , at 535 ; Ohlander, supra note 2 , at 257 .

83 Wright v. Louisville \& Nashville R. Co. (1904) 195 U. S. 219, 25 Sup. Ct. 16. See State cases cited in Note (1910) 15 Ann. Cas. 895. In California, such taxation is prohibited by section 3608 of the Political Code. However, the prolibition applies only to double taxation by California. It is not a violation of the section to tax the shares where the property of the corporation is also taxed, not by California, but by another state. San Francisco v. Fry (1883) 63 Cal. 470; Chesebrough v. San Francisco (1908) 153 Cal. 559, 96 Pac. 288.

84 In an opinion rendered to the State Tax Commission, the Attorney General of New York declared that nothing in Farmers' Loan and Trust Company v. Minnesota could be construed as denying the power of the state of incorporation to tax shares of its own corporations, though owned by non-residents. He relied Leavily on the decision in Frick v. Pennsylvania (1925) 268 U. S. 273, 45 Sup. Ct. 603,42 A. L. R. 316, lrolding that although the state of the shareholder's domicile could levy an inheritance tax on stock of a foreign corporation, it must first deduct the tax due to the state of incorporation, as that state had superior power to tax and that before the state of the shareholder's domicile could be regarded as laving any power over the shares at all, the tax due the state of incorporation must be paid. Payment of the tax to the state of incorporation was regarded as necessary to bring the slares within the taxing jurisdiction of the state of the sbarelrolder's domicile. 268 U. S. at 497,45 Sup. Ct. at 607,42 A. L. R. at 325 . The Attorney General also said: "The uncertainties which these three opinions may leave as to possible extensions of the doctrine of Farmers' Loan and Trust Company v. Minnesota to cases of corporate stock and other intangibles, are reinforced upon consideration of subsequent changes in personnel of the court." Opinion of the Attorney General to the State Tax Commission (May 14, 1930) 5 U. S. Daily 934. In City Bank Farmers' Trust Company v. New York Central R. Co. (1930) 253 N. Y. 49,170 N. E. 489 , Mr. Cbief Judge Cardozo allowed a tax on the stock of a domestic corporation, owned by a non-resident, on the ground that there was no reciprocity between New York and Pennsylvania during the period in question, and refused to give any opmion as to whether the state had constitutional power to levy the tax, on the ground that counsel bad not raised the point in the lower court. $170 \mathrm{~N}$. E. at 494. 
debts to this different type of intangible. It must choose the one jurisdiction that will be permitted to tax the shares. In so choosing, at least five jurisdictions are available for choice:

(1) State of incorporation

(2) Domicile of shareholder

(3) Where stock certificates are physically present

(4) Where stock transfer books are kept

(5) Where shares have acquired a business situs.

(1) State of Incorporation.

Perhaps no theory has been more generally followed in the past than that which permits the state of incorporation to tax the shares of the corporation it creates, at their full market value, whether those shares are owned by residents or non-residents. ${ }^{85}$ Yet, perhaps no theory which has received such general acceptance has as few supporting cases setting forth any cogent or other reasons for its existence. Most cases assume the point without argument. ${ }^{86}$ A great many place the

85 Corry v. Baltimore (1905) 196 U. S. 466, 25 Sup. Ct. 297, apparently so holds, but the case is not clearly authority for this proposition as the corporation had assented to the tax in its charter, and the Court relied on this fact in its opinion. See 196 U. S. at 473, 25 Sup. Ct. at 299. See also Tappan v. Merchants' Nat. Bank (1873) 86 U. S. (19 Wall.) 490; Travelers' Ins. Co. v. Connecticut (1902) 185 U. S. 364, 22 Sup. Ct. 673; Baker v. Baker Eccles \& Co. (1917) 242 U. S. 394, 37 Sup. Ct. 152; Maxwell v. Bugbee (1919) 250 U. S. 525, 40 Sup. Ct. 2; Frick v. Pennsylvania (1925) 268 U. S. 473, 497, 45 Sup. Ct. $603,607,42$ A. L. R. 316, 325. For a list of state cases so holding, see Note (1926) 42 A. L. R. 354, 365 ; Note (1929) 60 A. L. R. 565, 567; Note (1930) 65 A. L. R. 1008; Note Ann. Cas. 1918A 555; Note L. R. A. 1915C 903, 944 (property tax cases). See also Ohlander, supra note 2, at 256; Brady, supra note 2, at 533; Kroeger, supra note 4, at 125; Beale, Jurisdiction to Tax (1919) 32 Harv. L. REv. 587, 602; GoodrICH, CONFLICT of Laws (1927) \$\$51, 52; Nossaman, supra note 2, at 357; Note (1930) 10 B. U. L. REv. 423, 427; Note (1926) 14 CaIIF. L. REv. 225, 226, note 7; Note (1930) 30 CoL. L. Rev. 404; Note (1925) 38 Harv. L. Rev. 808, 811 ; Note (1930) 43 Fiarv. L. REv. 792, 797; Note (1930) 28 Micr. L. REv. 916, 917; Note (1930) 8 N. C. L. Rev. 318, 321; Note (1930) 64 U. S. L. REv. 160.

86 Inheritance Tax cases: McDougald v. Low (1912) 164 Cal. 107, 127 Pac. 1027; McDougald v. Lilienthal (1917) 174 Cal. 698, 164 Pac. 387, L. R. A. 1917F 267 (see also Murphy v. Crouse (1901) 135 Cal. 14, 66 Pac. 971); People v. Griffith (1910) 245 IIl. 532, 92 N. E. 313; DeWitt v. Commonwealth (1919) 184 Ky. 437, 212 S. W. 437; State ex rel. Graff v. Probate Court (1915) 128 Minn. 371,150 N. W. 1094, L. R. A. 1916A 901; Gardiner v. Carter (1908) 74 N. H. 507, 69 Atl. 939; Security Trust Co. v. Edwards (1917) 90 N. J. L. 558, 101 Atl. 384, L. R. A. 1917F 273; Beers v. Edwards (1913) 84 N. J. L. 32, 85 Atl. 1022; Penfold v. Edwards (1915) 87 N. J. L. 461, 95 Atl. 128; $R e$ Delano (1908) 74 N. J. Eq. 365, 69 Atl. 482; Maxwell v. Edwards (1917) 90 N. J. L. 707, 101 Atl. 248; Hill v. Bugbee (1918) 91 N. J. L. 454, 103 Atl. 861; Macmiller v. Bugbee (1925) 130 Atr. (N. J. L.) 660 ; Re Cooley (1906) 186 N. Y. 220, 78 N. E. 939, 10 L. R. A. (N. S.) 1010; Re Palmer (1905) 183 N. Y. 238, 76 N. E. 16; State \& City Bank \& Trust Co. v. Doughton (1924) 188 N. C. 762 , 125 S. E. 621 ; Memphis Trust Co. v. Speed (1905) 114 Tenn. 67\%, 88 S. W. 321; Larson v. MacMiller 
theory on the ground that the property and the business of the corporation are within the state of incorporation. ${ }^{87}$ Since Rhode Island Hospital Trust Company v. Doughton, ${ }^{88}$ it has been settled that the state where the property of a corporation is situated may not, on that basis alone, tax the shares of stock of such corporation. It is difficult to see how the mere fact that such state is also the state of incorporation can give the presence of such property in the state any added significance. Other courts declare that since the state has created the corporation and its shares, it may tax them. ${ }^{89}$ But surely it cannot be maintained that the mere fact that the state has created property gives it the right to tax that property regardless of its situs or the residence of its owner.

(1920) 56 Utah 84, 189 Pac. 579; Commonwealth v. Huntington (1927) 148 Va. 97, 138 S. E. 650; Travelers' Ins. Co. v. Connecticut (1902) 185 U. S. 364, 22 Sup. Ct. 673.

Property Tax cases: Whitney v. Ragsdale (1870) 33 Ind. 107, 5 Am. Rep. 185; Bitayor of Baltimore v. Baltimore City Passenger Co. (1881) 57 Md. 31; McKennon v. McFall (1912) 127 Tenn. 393, 155 S. W. 158; Abingdon Bank v. Washington County (1891) 88 Va. 293, 13 S. E. 407; Union Bank v. Richmond (1897) 94 Va. 316, 26 S. E. 821; Scandinavian-American Bank v. Pierce County (1898) 20 Wash. 155, 55 Pac. 40.

87 Inheritance Tax cases: Re Culver (1909) 145 Iowa 1, 123 N. W. 743, 25 I. R. A. (N. S.) 384; Greves v. Shaw (1899) 173 Mass. 205, 53 N. E. 372 ; $R e$ Bronson (1896) 150 N. Y. 1, 44 N. E. 707, 55 Am. St. Rep. 632, 34 L. R. A. 238. Property Tax case: St. Albans v. National Car Co. (1884) 57 Vt. 68.

88 Rhode Island Hospital Trust Co. v. Doughton (1926) 270 U. S. 69, 46 Sup. Ct. 256, 43 A. L. R. 1374. The decision was in accord with the weight of federal and state authority: Tyler v. Dane County (W. D. Wis. 1923) 289 Fed. 843; State cx rel. Peterson v. Dunlap (1916) 28 Idaho 784, 156 Pac. 1141, Ann. Cas. 1918A 546; People v. Dennett (1916) 276 Ill. 43, 114 N. E. 493; Welch v. Treasurer \& Receiver General (1916) 223 Mass. 87, 111 N. E. 774; State ex rel. Bankers' Trust Co. v. Walker (1924) 70 Mont. 484, 226 Pac. 894; In re Estates of Harkness (1921) 83 Okla. 107, 204 Pac. 911, 42 A. L. R. 399; Estate of Shepard (1924) 184 Wis. 88, 197 N. W. 344 . Although one writer was surprised "to find that the corporate veil is lined with the impregnable armor of the Fourteenth Amendment," Note (1925) 23 Micr. L. REv. 272, 274; Note (1926) 24 Micr. L. REv. 733, it was quite generally approved. Note (1926) 26 Cor. L. REv. 763; Note (1926) 15 GEo. L. J. 89; Note (1926) 39 Harv. L. REv. 898; Note (1926) 10 MLNN. L. Rev. 631; Note (1926) 12 VA. L. REv. 595. But see Note (1927) 15 CaLIF. L. Rev. 248.

89 American Coal Co. v. County Commrs. (1882) $59 \mathrm{Md}$. 186, where the court said: "The appellant is a Maryland corporation, deriving its existence, and all its powers and franchises, from this State. And such being the case, it is settred, that the sovereign power of taxation extends to everything which exists by the authority of the State, or which is introduced by its permission, ... " $59 \mathrm{Md}$. at 193. In Neilson v. Russell (1908) 76 N. J. L. 27, 69 Atl. 476, the court said: "In fine, we thimk that the sovereign power to which a corporation owes its existence can never be wholly detached from it, and is not estranged from its creature by the circumstance that the owners of shares in the property thus created resided in one place rather than in another. The metaphor that pictures the State as giving birth to a corporation is a figure more bold than accurate, for (to carry out the metaphor) the natal cord between the two is never completely severed." 76 N. J. L. at 38, 69 Atl. at 481 . See also Beale, supra note 85 , at 602. 
In regard to succession taxes, it is said that the state of incorporation is necessary to effect a transfer. ${ }^{90}$ While this is usually true, ${ }^{91}$ it would seem that it can be of no avail as an argument since the overruling of Blackstone v. Miller and Wheeler v. Sohmer by Baldwin v. Missouri. The law of the debtor's domicile was necessary to effect a transfer of the bank deposit involved in the Baldrein case, and yet this was not deemed a sufficient basis for a tax. Sometimes the fact that the corporation is a citizen of or is domiciled in the state of incorporation is adverted to as a justification for the tax. ${ }^{92}$ If the tax were on the corporation this would of course be a justification. Since the tax is on the shareholder, however, this consideration seems wholly irrelevant. Cases where the device of taxing shares is in lieu of the tax on the property of the corporation ${ }^{93}$ are of course not pertinent here. The same may be said of cases where the state, in granting a corporate charter, lias annexed the condition that the shares, whether owned by a resident or a non-resident, shall have a situs for taxation in the state of incorporation. ${ }^{94}$ A very few cases have showed their disfavor for the whole doctrine by either refusing to follow it, ${ }^{95}$ or by construing the

90 State ex rel. Bodman v. Probate Court (1919) 142 Minn. 415, 172 N. W. 318; Douglas County v. Kountze (1909) 84 Neb. 506, 121 N. W. 593; Nickel v. State (1919) 43 Nev. 45, 185 Pac. 565. The fact that the state of incorporation regulates the transfer of the shares is sometimes mentioned to sustain a property $\operatorname{tax}$ on shares by the state of incorporation. Street R. Co. v. Morrow (1889) 87 Tenn. 406, 11 S. W. 348, 2 L. R. A. 853; St. Albans v. National Car Co. (1884) 57 Vt. 68.

81 Under the Uniform Stock Transfer Act the stock certificate becomes the important eleinent in the passing of title. Unless the certificate is delivered, no title passes. UnIForm Stock Transfer Act \$1.

92 Greves v. Shaw (1899) 173 Mass. 205, 53 N. E. 372.

93 Faxton v. McCosh (1861) 12 Iowa 527.

94 Corry v. Baltimore (1905) 196 U. S. 466, 25 Sup. Ct. 297; Koochiching v. Mitchell (1919) 186 Iowa 1216, 173 N. W. 151.

95 City and County of San Francisco v. Mackey (C. C. D. Cal. 1884) 22 Fed. 602 ; North Carolina R. Co. v. Commissioners of Alamance (1884) 91 N. C. 454 ; Union Bank v. State (1836) 17 Tenn. 373 ( 9 Yerg. 489); Mayor of Nashville v. Thounas (1868) 45 Tenn. 493 (5 Cold. 600). The argument set forth in these cases is that since shares are mere choses in action, they have a situs at the doinicile of their owner, under mobilia sequnntur personam; that since they liave such a situs, they cannot have a situs elsewhere. These cases cannot be regarded as authoritative today, however. The Mackey case was merely construing a statute and not the state's constitutional power to tax, although intimating that the state of incorporation had no constitutional power to levy a tax on shares owned by a non-resident. See 22 Fed. at 604 . The Tennessee cases were overruled in Bedford v. Mayor of Nashville (1872) 54 Tenn. 339 (7 Heisk. 409). A North Carolina statute taxing shares in domestic corporations, whether owned by residents or nonresidents was sustained in Board of Commissioners v. Blackwell Durham Tobacco Co. (1895) 116 N. C. 441, 21 S. E. 423, although in the latter case it appeared that the tax was in lieu of a corporation franchise tax. 
state tax statute as not attempting to levy such a tax,, 98 or by holding, when the corporation is incorporated in several states, that a tax on the shares by the state of incorporation could not be measured by the full market value of the shares, but must be apportioned, according to the amount of property of the corporation in the state. ${ }^{97}$ Few cases exist where all the court had before it as a basis of taxation was the simple fact of incorporation, unmixed with these other elements. ${ }^{08}$ This of course accounts for the lack of cases attempting to support taxation on that basis alone. Consequently, not much help may be obtained from the authorities in settling the problem.

Two arguments may be urged in support of the theory that the state of incorporation may tax the shares: (1) the fact that the law of the incorporating state protects the chose in action in the same way as it protects a debt, by protection of the corporation and its property and by permitting resort to its courts to enforce the same; (2) the shareholders, whether resident or non-resident, participate in the enjoyment of a privilege - the franchise to be a corporation, and therefore the state may tax that privilege.

The first argument is, of course, merely another form of the doctrine of Blackstone v. Miller. However logical the considerations in support of it, there is no longer any room for it.

The second argument appears to lack substance, if we admit that

${ }^{96}$ Neilson v. Russell (1908) 76 N. J. L. 655,71 Atl. 286, 19 L. R. A. (s. s.) $\delta 87$ (Pitney, Bergen and Green dissenting). In 1909 the New Jersey statute was amended to expressly levy such a tax. N. J. Acts 1909, 325. The statute was sustained in Carr v. Edwards (1913) 84 N. J. L. 667, 87 Atl. 132.

${ }^{07}$ Kingsbury v. Chapin (1907) 196 Mass. 533, 82 N. E. 700, 13 Ann. Cas. 738; $\operatorname{Re}$ Cooley (1906) 186 N. Y. 220, 78 N. E. 939, 10 L. R. A. (N. S.) 1010. But the cases are just as empbatic in holding that there can be no deduction from the full market value of the shares due to the fact that part or all of the property of the corporation is beyond the jurisdiction of the taxing state-where the corporation is incorporated in only one state, i.e. the taxing state. State ex rel. Bodman v. Probate Court (1919) 142 Minn. 415, 172 N. W. 318 (only 27 per cent of property in Minnesota); Re Palmer (1905) 183 N. Y. 238, 76 N. E. 16.

98 Only two such cases have been found. City and County of San Francisco v. Mackey (C. C. D. Cal. 1884) 22 Fed. 602, holding that the tax could not be levied hecause the legislature had not provided for it, and Koochiching v. Mitchell (1919) 186 Iowa 1216, 173 N. W. 151, which sustains the tax on the ground that the state had annexed a condition to the grant of the corporate franchise that the shares should be taxable by the state of incorporation, by whomever owned. 186 Iowa at $1220,173 \mathrm{~N}$. W. at 152 . Whether the state may constitutionally annex such a condition to the grant of a corporate franchise must be, in view of the language of the Court in Frost \& Frost Trucking Co. v. Railroad Commission (1926) 271 U. S. 583, at 593, 46 Sup. Ct. 605, at 607, be regarded as debatable. See Oppenheim, Unconstitutional Conditions (1927) 26 MICH. L. REv. 176; Merrill, Unconstitutional Conditions (1929) 77 U. of PA. L. Rev. 879. See Note (1930) 8 N. C. L. REv. 318,322 , to the effect that it cannot. 
the state of incorporation may also exact a franchise tax from the corporation itself. Such a franchise tax is a privilege or excise tax, levied either on the right to be a corporation, or the privilege of doing business in the corporate form. The privilege of being a corporation or of doing business in the corporate form, is in reality conferred on the shareholders and not the corporation. To tax the corporation for this privilege is obviously to misuse words. Such a tax is in reality merely a device for taxing the shareholders on that privilege, for it is they, and not the corporation, upon whom the privilege is conferred. Conseuently, the shareholders have already paid once for the privilege. To tax the shares and then attempt to justify such tax as one on a privilege enjoyed by the shareholders is arbitrary, and clearly an example of double taxation. It will not do to say that the state, when it levies a tax measured by the shares, is merely taxing the shareholders for the privilege of being shareholders. ${ }^{99}$ The privilege of being a shareholder is not an entirely distinct privilege, but one incidental to and included in the grant of the main privilege to be a corporation. To hold otherwise would lead to strange results, for by the same sort of logic, a tax on the president of a corporation for the privilege of being president; on the hod-carrier for the privilege of working for a corporation; and on the manufacturer for the privilege of trading with a corporation, could be justified. Such a startling possibility would seem to demonstrate the fallacy in the above proposition.

Consequently, a state should not be permitted to tax the nonresident shareholders on their shares unless such tax is in lieu of the franchise tax on the corporation. ${ }^{100}$ To hold otherwise is to sanction unjust and oppressive double taxation. If this theory be adopted, it follows that the state of incorporation may always levy an inheritance $\operatorname{tax}$ on the franchise, but it should not be permissible to measure such a tax by the market value of the shares as is now done by the state of incorporation. This is obviously not the real value of the franchise, nor has it any necessary relation to its real value..$^{101}$ The value must,

99 Beare, Foreign Corporations (1904) \$736.

100 See State v. Travelers' Ins. Co. (1898) 70 Conn. 590, 40 Atl. 465, 66 Am. St. Rep. 138; Board of Commissioners v. Blackwell Durham Tobacco Co. (1895) 116 N. C. 441,21 S. E. 423 ; Note (1930) 8 N. C. L. Rev. 318, 323.

101 " ... when the franchise granted is simply the franchise to be a corporation, that franchise can have no greater value than what it has cost the incorporators to obtain it and what it would cost other incorporators to obtain the identical privilege. Since in this State these franchises are open to all upon the same conditions, that cost is the mere expense of filing papers and procuring clerks' certificates, say ten dollars, and it cannot be said that such a franchise or privilege can ever be worth more than the amount while our laws remain unchanged." Concurring opinion of Mr. Justice Henshaw in Crocker v. Scott (1906) 149 Cal. 597, 87 Pac. 102, at 111. 
in most cases, be only nominal, i.e. what it would cost others to obtain a like privilege. If the theory suggested be adopted, the tax on the shares becomes in effect a franchise tax. There is still one state left which may tax the shares themselves at their market value.

The case of Beidler v. South Carolina Tax Commission ${ }^{102}$ may shed some light on the problem. It is now pending before the United States Supreme Court. A holding to the effect that the state of incorporation could not tax will necessitate the overruling of Corry v. Baltimore ${ }^{103}$ in part, and Frick v. Pennsylvania in part. ${ }^{104}$ On the other hand, if the Court decides to sustain the power of the state of incorporation to tax the shares of non-residents at their full market value it must, in order to avoid bi-state taxation, make an exception to its previously favored theory - that of mobilia sequuntur personam. This would necessitate the overruling of Hawley v. Malden.105

102 (1930) 5 U. S. Daily 1007. The facts are as follows. Beidler died a resident of Illinois. A certain corporation, organized in South Carolina, and whose business was carried on wholly in South Carolina owed Beidler $\$ 556,000$ on account of moneys loaned and $\$ 64,000$ on dividends declared but unpaid. The majority of the company's stock was owned by Beidler. A tax on both the credits by the state of South Carolina was sustained by the South Carolina Supreme Court (not reported). An appeal was taken to the United States Supreme Court. Since a dividend declared but unpaid is nothing more than a debt (Bariantine, Corporations (1927) 502), the tax on the dividends must be controlled by Farmers' Loan and Trust Co. v. Minnesota, and the overruling of Blackstone v. Miller. If the tax on the dividends is treated as in effect on the shares, the question will then be squarely presented for decision by the Court. See Opinion of Attorney General to Tax Commission, supra note 84, apparently so treating the Beidler case. See (1930) 5 U. S. Daily 1007, for facts in detail of the Beidler case. See also Ohlander, sispra note 2, at 258, for same. Although Fisher v. Brucker (E. D. Mich. 1930) 41 F. (2d) 774 was expected to decide the point (see Ohlander, supra note 2, at 257), the Court dodged the issue and decided on the basis of reciprocity tax statutes. See (1930) U. S. Daily 1421; Ohlander, supra note 2, at 257, note 8a. But apparently the point is squarely involved in a case pending in Kentucky. See Ohlander, supra note 2, at 257, note 8a, and in two New York cases, Brady, supra note 2, at 534, note 15 , so that the United States Supreme Court will probably be compelled to decide the point during the October 1930 Term.

103 (1905) 196 U. S. 466, 25 Sup. Ct. 297, -although the case is explainable on other grounds. See supra note 85.

104 "The decedent owned many stocks in corporations of States, other than Pennsylvania, which subjected their transfer on death to a tax and prescribed means of enforcement which practically gave those States the status of lienors in possession. As those States had created the corporations issuing the stocks, they had power to impose the tax and to enforce it by such means, irrespective of the decedent's domicile and the actual situs of the stock certificates. Pennsylvania's jurisdiction over the stocks necessarily was subordinate to that power." 268 U. S. at 497,45 Sup. Ct. at 607,42 A. L. R. at 325.

105 (1914) 232 U. S. 1, 34 Sup. Ct. 201. Mr. Justice Hughes raised the following question: "Whether, in the case of corporations organized under state laws, a provision by the State of incorporation fixing the situs of shares for the pur- 


\section{(2) Domicile of Shareholder.}

If the Court should deny the power of the state of incorporation to tax the shares at all, it may then dispose of the problem of where the shares may be taxed by simply applying the rules developed by the Farmers' Loan and Baldwin cases. This would sanction a tax by the state of the domicile of the shareholder in all cases, unless the shares acquire a business situs elsewhere. ${ }^{106}$

(3) Where the Stock Certificates Are Physically Present.

The overruling of Wheeler $v$. Sohmer and the doctrine that the evidences of a chose in action may be treated as tangibles, makes it extremely unlikely that any cases in the future will attempt to predicate jurisdiction to tax the shares on the mere physical presence of the certificates, although prior to the Farmers Loan and Baldwin cases, there were instances of this being done, ${ }^{107}$ especially under the influence of the Uniform Stock Transfer Act and the Federal Supreme Court ruling in the Disconto-Gesellschaft case. ${ }^{108}$ Under the Uniform Stock Transfer Act, the certificate assumes a much more important role than ever before. Under that Act, legal title to the shares may not be transferred without dehivery of the certificate. ${ }^{109}$ The certificate which, even in the absence of the Act, had many attributes of a negotiable instrument, ${ }^{110}$ becomes completely negotiable under the Act. ${ }^{111}$ However,

pose of taxation of the shares by others States in which their owners reside is a question which does not arise upon this record and need not be decided." 232 U. S. at 12,34 Sup. Ct. at 203 . It was held that such a provision did not exclude taxation by the state of the owner's domicile in Bellows Falls Power Co. v. Commonwealth (1915) 222 Mass. 51,109 N. E. 891.

106 Infra note 113.

107 In Newell v. Tremont Lumber Co. (1926) 161 La. 649, 109 So. 344, jurisdiction of Louisiana, the state of incorporation, to tax shares of stock, was denied solely on the ground that the certificates were outside the state, Louisiana having adopted the Uniform Stock Transfer Act. See also Stern v. The Queen [1896] 1 Q. B. 211, and Rhode Island Hospital Co. v. Doughton (1926) 270 U. S. 69, 79, 46 Sup. Ct. 257, 258, 43 A. L. R. 1374, 1378. The following are to the contrary: People v. Griffith (1910) 245 IIl. 532, 92 N. E. 313; Kennedy v. Hodges (1913) 215 Mass. 112,102 N. E. 432; Re James (1894) 144 N. Y. 6, 38 N. E. 961 ; Cassidy v. Ellerhorst (1924) 110 Ohio St. 535,144 N. E. 252,42 A. L. R. 372. See Kroeger, supra note 4, at 129; Note (1925) 38 HARv. L. REv, 809, 814; Note (1926) 14 CAIIF. L. REv. 225, 226, note 7; Nossaunan, supra note 2, at 357.

108 Direction der Disconto-Gesellschaft v. United States Steel Corporation (1925) 267 U. S. 22, 45 Sup. Ct. 207 (holding that a seizure by the English Public Trustee of certificates pledged in England by German banks was good against the latter and that the corporation was bound to transfer the stock on its books). See Note (1927) 15 CaIIF. I. REv. 145, 147. See also New York ex rel. Hatch v. Reardon (1907) 204 U. S. 152, 161, 27 Sup. Ct. 188, 191.

109 Uniform Stock Transfer Act \$1. Cf. Note (1927) 15 CaIIF. L. Rev. 145, 147.

110 Batlantine, Corporations (1927) 473.

111 Turnbull v. Longacre Bank (1928) 249 N. Y. 159, 163 N. E. 135. See Note (1929) 17 CALIF. L. REv. 403, 409. 
since the doctrine that negotiable instruments may be assimilated to tangibles is now repudiated, it would appear that there is no longer any room for this doctrine. Under the present theory full negotiability will not aid. Therefore the Umiform Stock Transfer Act, or any other argument emphasizing the negotiable characteristics of certificates can be of no avail. Unless negotiability reaches such a point that the instrument is converted into a medium of exchange, ${ }^{112}$ the chose is not taxable where the instrument is physically present.

(4) Where Stock Transfer Books Are Kept.

The Enghish method of determining the situs of shares for purposes of taxation is by applying the simple test: "Where can the shares be effectively dealt with?" The answer to this question determines the situs of the shares. The English cases have answered this question by holding the place where the shares may be effectively dealt with is the place where. they may be transferred. ${ }^{113}$ Consequently the situs of shares of stock is held to be at the place where the stock transfer books of the corporation are kept. The English rule is extremely practical, and much could be said for its adoption in this country if the United States Supreme Court had not prevented this by its holdings in Farmers Loan and Trust Company v. Minnesota and Baldwin v. Missouri. The place where public bearer bonds may be effectively dealt with is certainly the place where the instruments actually are, and yet that jurisdiction is demied the power to tax under these holdings. Therefore the English theory must be regarded as rejected as far as this country is concerned.

(5) Business Situs of Shares.

While no cases have been found predicating jurisdiction to tax shares on the business situs doctrine, there is no reason why that doctrine should not extend to all intangibles, including shares of stock. The case of National Leather Company v. Massachusetts ${ }^{114}$ strongly

112 Blodgett v. Silberman (1928) 277 U. S. 1 at 18, 48 Sup. Ct. 410 at 416 (bank notes, passing as currency, unay be assimilated to tangibles).

113 Brassard v. Smith [1925] A. C. 371; Erie Beach Co. v. Attorney-Gen. for Ontario [1930] A. C. 161 (upholding tax at place where transfer books kept). See Note (1930) 8 Canada Bar Rev. 311; Note (1925) 38 HaRv. L. Rev. 809, 812, note 17, 815; Kroeger, supra note 4, at 133 . See also Cutting v. The King [1930] 2 D. L. R. 297 , denying the power of the province where the principal office of a bank was situated to tax the shares, since the transfer books were kept in New York. Cf. Royal Trust Co. v. Attorney-Gen. for Alberta [1930] A. C. 144, supra note 3.

114 (1928) 277 U. S. 413, 48 Sup. Ct. 534, holding that it was permissible for Massachusetts, in computing a franchise tax on a Maine corporation, doing business in Massachusetts, to include in the assessment the value of the stock of two subsidiary Maine corporations because they were "assets employed by the petitioner in its busmess within the State, ..." 277 U. S. at 423,48 Sup. Ct. at 536. 
intimates that shares of stock may acquire such a business situs for taxation.

\section{CONCLUSION}

It would seem to the writer that the Supreme Court is to be both commended and rebuked in this, the most drastic change in the law it has ever effected. It is to be commended for its frank attempt to check what most will admit was a growing evil, i.e. multi-state taxation of intangibles. ${ }^{116}$ It is to be commended for performing a service which could not have been as effectually performed in any other way, retaliatory tax statutes designed to accomplish the same end having proved but a moderately successful palliative. ${ }^{116}$ It is to be rebuked, however,

Although the tax was not a tax on property but on the franchise, a franchise tax, as has been observed (supra note 10) is coming to be regarded as the practical equivalent of one on the property of which it is measured. Macallen Co. v. Massachusetts (1929) 279 U. S. 620 , 49 Sup. Ct. 432, 65 A. L. R. 866. See Traynor, supra note 10, at 456; Powell, The Macallen Case-and Before (1930) 8 Nat. Inc. TAX Mag. 47; Powell, The Macallen Case - and Beyond (1930) 8 Nat. Inc. TAX MAG. 91; Note (1930) 43 HARv. L. Rev. 280. See also Aberdeen Savings \& Loan Assn. v. Chase (1930) — Wasb. -, 289 Pac. 536.

115 Wickersham, Double Taxation (1925) 12 VA. L. REv. 185; Seligaran, Double Taxatron and Internatronal Fiscat CoOperation (1928); Note (1930) 43 Harv. L. Rev. 792; City Bank Farmers' Trust Co. v. New York Cent. R. Co. (1930) 253 N. Y. 49 , 170 N. E. 489 ; (1930) 5 U. S. Daily 880 . Cf. Harper, Jurisdiction of the States to Tax (1930) 9 ORE. L. Rrv. 370, 376.

116 The reciprocity movement commenced on a large scale in 1924. The essence of the plan was that "State $A$ agreed to discontinue imposing an inheritance tax on intangible property of State B if State B granted a like exemption to residents of State A." Ohlander, supra note 2, at 253. It is thus seen that the state's freedom of action is very shightly restricted, if at all. If it desired (before Farmers' Loan and Trust Co. v. Minnesota) to tax imtangibles of non-residents, it could do so. The only penalty was the subjection of like treatment of its own citizens by reciprocity states. Accordingly, the reciprocity device will only be called into play when "the self interest of the state, other than its antipathy for double taxation, really indicates a more sweeping remedy." Legislation (1930) 43 HARv. L. REV. 641, 646. It is said that thirty-seven states have adopted reciprocity tax statutes in some form. City Bank Farmers' Trust Co. v. New York Cent. R. Co. (1930) $170 \mathrm{~N}$. E. at 490 . Cf. Nossaman, supra note 2 , at 362 , note 71 . "Many states have even gone further than this and have abolished inheritance or succession taxes upon intangible personal property of nonresident decedents. These states are Colorado, Connecticut, Delaware, Massachusetts, New Jersey, Rhode Island, Tennessee, Vermont, and Virginia." Ohlander, supra note 2 , at 254 . Some of the shortcomings of the reciproctiy movement statutes might be listed as follows: (1) "Since taxation is seldom motivated by disinterestedness ... it would be surprising if debtor states could agree to a rule of taxation which would appeal to creditor states." Note (1930) 43 HARv. L. REv. 792, 795. (2) Variation in terminology between different statutes means doubt as to the existence of reciprocity between states. Legislation (1930) 43 Harv. L. REv. 641, 643; e.g. City Bank Farmers' Trust Co. v. New York Cent. R. Co., supra; Fisher v. Brucker (E. D. Mich. 1930) 41 F. (2d) 774 ; 5 U. S. Daily 1421; Commonwealth v. Farmers' Loan and Trust Co. (1930) - Pa. —, - Atl. -; (1930) 5 U. S. Daily 1353. 
for not giving a more adequate and careful analysis in the selection of the one state which may, in the future, tax intangibles - for excluding states which would seem to have a better claim than the state of the owner's domicile.

$$
\text { J. C. Peppin. }
$$

Berketey, CALIFORNIA.

(3) "Variant judicial and administrative rulings as to what constitutes tangible and intangible property make it chaotically uncertain whether one state, in spite of its statute, is entitled to reciprocity with another." Legislation (1930) 43 Harv. L. REv. 641, 644. That reciprocal tax statutes are not as effective a remedy for multiple taxation as judicial decision, see Note (1930) 43 HARv. L. REv. 792; Legislation (1930) 43 HARv. L. REv. 641, 646. Cf. dissenting opinion of Mr. Justice Holnes in Baldwin v. Missouri, 281 U. S. at 596, 50 Sup. Ct. at 439; Nossaman, supra note 2 , at 363 . 